First draft: August 2011

This draft: October 2011

\title{
Sovereign debt, government myopia, and the
}

\author{
financial sector $^{1}$
}

\author{
Viral V. Acharya \\ NYU-Stern, CEPR, \\ ECGI and NBER
}

\author{
Raghuram G. Rajan \\ Booth School of Business \\ University of Chicago and NBER
}

What determines the sustainability of sovereign debt? In this paper, we develop a model where myopic governments seek electoral popularity but can nevertheless commit credibly to service external debt. They do not default when they are poor because they would lose access to debt markets and be forced to reduce spending; they do not default when they become rich because of the adverse consequences to the domestic financial sector. Interestingly, the more myopic a government, the greater the advantage it sees in borrowing, and therefore the less likely it will be to default (in contrast to models where sovereigns repay because they are concerned about their long term reputation). More myopic governments are also likely to tax in a more distortionary way, and create more dependencies between the domestic financial sector and government debt that raise the costs of default. We use the model to explain recent experiences in sovereign debt markets.

\section{J.E.L.: E62, G2, H63,}

Keywords: ability to pay, willingness to pay, sovereign default, political economy

\footnotetext{
${ }^{1}$ We thank Itamar Drechsler, Mitu Gulati, Olivier Jeanne, Gregor Matvos,and Philipp Schnabl for helpful conversations, and Xuyang Ma for excellent research assistance. We also received useful comments from seminar participants at Boston University, Conference on Sovereign Debt and Crises in Iceland (October 2011), European Economic Association (EEA) and Econometric Society European Meeting (ESEM) Meetings - 2011, National Bank of Hungary, Queen's University and the University of Calgary. Rajan acknowledges support from the Stigler Center and the Initiative on Global Markets at the University of Chicago's Booth School and from the National Science Foundation.
} 
Why do governments repay external sovereign borrowing? This is a question that has been central to discussions of sovereign debt capacity, yet the answer is still being debated. ${ }^{2}$ Models where countries service their external debt for fear of being excluded from capital markets for a sustained period (or some other form of harsh punishment such as trade sanctions or invasion) seem very persuasive, yet are at odds with the fact that defaulters seem to be able to return to borrowing in international capital markets after a short while. ${ }^{3}$ With sovereign debt in industrial countries at extremely high levels, understanding why sovereigns repay foreign creditors, and what their debt capacity might be, is an important concern for policy makers and investors around the world. This paper attempts to address these issues.

A number of recent papers offer a persuasive explanation of why rich industrial countries service their debt without being subject to coordinated punishment. ${ }^{4}$ As a country becomes more developed and moves to issuing debt in its own currency, more and more of the debt is held by domestic financial institutions, or is critical to facilitating domestic financial transactions because it is risk-free, interest bearing collateral. Default on domestic bond holdings now automatically hurts domestic activity by rendering domestic banks insolvent, or reducing activity in financial markets (see especially Bolton and Jeanne (2011) or Gennaioli, Martin, and Rossi (2011)). If the government cannot default selectively on foreign holders of its debt only, either because it does not know who owns what, or it cannot track sales by foreigners to domestics (see Guembel and

\footnotetext{
${ }^{2}$ See, for example, Eaton and Gersovitz (1981), Bulow and Rogoff (1989a), Fernandez and Rosenthal (1990), Cole and Kehoe (1998), Kletzer and Wright (2000), and Tomsz (2004).

${ }^{3}$ See, for example Eichengreen (1987), Sandleris, Gelos, and Sahay (2004), and Arellano (2009). Ozler (1993) and Flandreau and Zumer (2004) find that increased premia on debt of past defaulters are too small to suggest strong incentives to pay.

${ }^{4}$ See, for example, Basu (2009), Broner, Martin, and Ventura (2010), Bolton and Jeanne (2011), and, Gennaioli, Martin, and Rossi (2011).
} 
Sussman (2009) and Broner, Martin, and Ventura (2010) for rationales), then it has a strong incentive to avoid default and make net debt repayments to all, including foreign holders of its debt.

What is less clear is why an emerging market or a poor country, that has a relatively underdeveloped financial sector, and hence little direct costs of default, would be willing to service its debt. Of course, one could appeal to reputation models where governments strive to maintain the long-term reputation of their country even though default is tempting. However, we are more realistic (or perhaps cynical). While there may be some such far-sighted governments, most governments care only about the short run, with horizons limited by elections or mortality - such short termism is perhaps most famously epitomized by Louis XV when he proclaimed "Apres moi, le deluge!" Shorthorizon governments are unlikely to see any merit in holding off default until their country becomes rich, solely because their reputation then will be higher - after all, the benefits of that reputation will be reaped only by future governments.

Short termism may, however, help in another way that explains why emerging markets or poor countries, with little cost of defaulting, still continue to service their debt. Short horizon governments do not care about a growing accumulation of debt that has to be serviced - they can pass it on to the successor government - but they do care about current cash flows. So long as cash inflows from new borrowing exceed old debt service, they are willing to continue servicing the debt because it provides net new resources. Default would only shut off the money spigot, as renegotiations drag on, for much of the duration of their remaining expected time in government. This may explain why some

\footnotetext{
${ }^{5}$ After me, the flood.
} 
governments continue servicing debt even though a debt restructuring may be so much more beneficial for the long-term growth of the country.

Thus we have a simple rationale for why developing countries may be able to borrow despite the absence of any visible mode of punishment other than a temporary suspension of lending; lenders anticipate the developing country will become rich, will be subject then to higher domestic costs of defaulting, and will eventually service its accumulated debt. In the meantime, the country's short-horizon government is unlikely to be worried about debt accumulation, so long as lenders are willing to lend it enough to roll over its old debts plus a little more. Knowing this, creditors are willing to lend to it today.

Key in this narrative, and a central focus of our analysis, are the policies that a developing country government has to follow to convince creditors that it, and future governments, will not default. To ensure that the country's debt capacity grows, it has to raise the future government's ability to pay (that is, ensure the future government has enough revenues) as well as raise its willingness to pay (that is, ensure the future penalties to default outweigh the benefits of not paying). The need to tap debt markets for current spending thus gives even the myopic government of a developing country a stake in increasing debt capacity. The policies that it follows will, however, potentially reduce the country's growth as well as increase its exposure to risk.

For instance, a higher tax rate will lead to lower real investment by the corporate sector, and therefore lower resources for a future government to tax, and a lower ability to pay. But it will also lead to more financial savings (because these typically escape the heavy taxes production is subject to), a larger holding of government bonds by domestic 
entities, and thus a greater willingness of future governments to service their debt for fear of doing widespread damage to the economy through default. This way, short-horizon governments' taxation decisions will be influenced significantly by their effect on debt capacity.

In deciding whether to service its legacy debt or not, a myopic developing country government has to trade off the benefits from added resources if it decides to service the debt against the distortions from taxing the economy so as to preserve access to debt markets. We trace out the maximum debt that countries will be able to service.

Interestingly, as the rate at which a government discounts the future falls (i.e., it becomes less myopic), its willingness to default on legacy debt increases. The longhorizon government internalizes the future cost of paying back new borrowing, as well as the distortions that stem from tax policies required to expand debt capacity. This makes borrowing less attractive, and since for a developing country government the ability to borrow more is the only reason to service legacy debt, the long-horizon developing country government has more incentive to default (or less capacity to borrow in the first place). Similarly, developing countries with a more productive technology may also have lower debt capacity because the distortionary taxation needed to sustain access to debt markets will be more costly for such countries. ${ }^{6}$

Finally, we also allow the government to determine the degree to which the financial sector becomes dependent on government debt (thus exposing the country to greater costs when the government defaults, and setting in place a greater future

\footnotetext{
${ }^{6}$ Greater borrowing by developing countries need not be associated with better fundamentals. Studies show that correcting for the obvious factors, developing countries that are more dependent on external financing seem to grow relatively slower (see, for example, Prasad, Rajan, and Subramanian (2007)), a puzzle that Aguiar and Amador (2009) suggest is explained by government borrowing).
} 
willingness to pay). We show that shorter horizon governments have a greater incentive to create more dependencies, in part because the future costs of default will not be borne by them, while the benefit of greater debt capacity will. To the extent that these dependencies emanate from the greater sophistication of the financial sector, a shorthorizon government has an incentive to create financial market institutions (such as repo markets) or liberalize the financial sector, in order to expand its own borrowing capacity. It may, however, do this to excess. We offer some examples in the paper.

It is useful to compare our model to the implications of existing models of external sovereign debt. In many of these models (see, for example, Eaton and Gersowitz (1981)), the cost of defaulting on foreign debt, either in terms of sanctions, exclusion from financial markets, or costs of higher future risk premia, have to be very high to outweigh the benefit of not repaying the enormous stock of debt. Hence, for example, "trigger" strategy models require punishment for a large number of periods if the borrower defaults. In our paper, though, the assumption of short government horizon ensures that the government emerging from poverty never internalizes the cost of repaying the entire stock of debt (or equivalently, the benefit from defaulting on it). All it cares about is whether the expected cash inflows from retaining access to the external debt market is positive over the remaining term of the government. If it is, the government will continue servicing debt, even if the only cost of default is the disruption of credit markets for a short while. ${ }^{7}$

\footnotetext{
${ }^{7}$ Indeed, that developing country governments myopically service their debts too long is consistent with the findings in Levy-Yeyati and Panizza (2006) that growth starts picking up in countries almost immediately after they default, while output declines steadily before. Of course, another explanation is the equilibrium one that only countries that benefit from default do so.
} 
Bulow and Rogoff (1989b) show that the reputational arguments for repayment break down because by defaulting and using asset markets to self-insure when net repayments have to be made, a country can guarantee itself higher consumption if it defaults than in if it does not. Anticipation of such default should preclude a country from borrowing in the first place. In a sense, our developing country government is a special case of Bulow-Rogoff, but our model clarifies that borrowing need not be impossible so long as future governments have the ability and willingness to pay too. This implies, however, a feasible time profile of repayments that cannot be exceeded.

More generally, because the costs of default are sizeable in our model only when the country becomes rich, the nature of developing country defaults and rich country defaults are likely to be very different. Developing countries are more likely to default when revenue shortfalls (crop failures or a fall in export prices) or increases in expenditure (natural disaster or a rise in import prices) lead to a buildup in debt that can imply net debt outflows for some time. The reason for default is not that the country cannot pay but that the time path of prospective payments does not make it worthwhile for the current government to maintain access to debt markets. For rich countries, though, the direct cost of default is substantial, and default looms only when the country simply does not have the political and economic ability to raise the revenues needed to repay debt.

Our model implies the sustainable level of debt for developing countries is likely significantly lower (see, for example, the evidence in Reinhart and Rogoff (2009a)), and that defaults could be cured with some re-profiling of the debt. However, it also implies that when rich countries are in danger of default, multilateral agencies like the IMF that 
lend them more without helping these countries expand productivity and growth are only postponing the inevitable messy restructuring. Finally, the observation that rich country defaults are more likely to be solvency defaults than liquidity defaults has implications for the current sovereign debt situation in Europe that we discuss later in the paper.

The rest of the paper is as follows. In section I, we present the simple model and analyze it in section II. We compare the short-horizon government's choices to those of a long-horizon government in section III. In section IV, we examine the effects of endogenizing the degree of dependence of the financial market on government debt. In section V, we discuss implications, in section VI the related literature, and then conclude. All proofs are in Appendix A and details of the numerical example are in Appendix B.

\section{The model}

Consider a world with three dates $(t=0,1,2)$ and two periods. The country that we focus on is emerging from poverty at date 0 , with a pre-existing debt of amount $D_{0}$ (it does not really matter whether this is private debt or government debt - it will have to be repaid by taxing the private sector). We assume this is entirely foreign borrowing, and is repayable to foreigners at end of the first period. Households and companies (collectively known as the private sector) have an endowment of $E_{0}$.

The private sector has access to a production technology which, in return for an investment $k_{1}$ during period 1, produces a return in the short run (end of period 1) of $f_{1}\left(k_{1}\right)$ as well as in the long run (end of period 2) of $f_{2}\left(k_{1}\right)$, with $f_{\bullet}^{\prime}>0, \quad f_{\bullet}^{\prime \prime}<0$. The remaining resources, $E_{0}-k_{1}$, represent financial savings which are invested in government bond markets or in the global capital markets. We assume universal riskneutrality and a time preference rate of $r$, which is thus the cost of borrowing in domestic 
as well as foreign debt markets. The private sector has a slight home bias, so if expected returns between the domestic market and foreign markets are equal, it prefers investing in the domestic market.

The government of the country is run by short-horizon politicians each period who want to maximize spending on populist schemes over the period, but do not consider the effects of their actions over the long term. Such myopic behavior could be explained by an inordinate desire to get re-elected (without considering the problems of governance if they are successful). Such spending could also be induced in a "rat race equilibrium" (see Holmstrom (1999)) where there is short-run opacity about true economic outcomes if sustainable jobs are harder to create, the politician may spend on make-work jobs so long as the public has a hard time distinguishing the two in the short run. Everyone knows the politician creates such jobs, and it is inefficient, but if he does less than the equilibrium amount, he will get punished for being ineffective. Clearly, extreme myopia is a caricature, and is only to make the effects of the model clear. Later, we will see what longer horizons might do, as well as consider the effects of more realistic objective functions.

The government can raise money for spending in two ways. First, it can levy taxes on the private sector of up to $t^{\text {Max }}$ every period on the cash flows generated from real investment - we assume this reflects the political and economic capacity of the government to collect tax revenues. We assume financial investments by the private 
sector are not taxed. ${ }^{8}$ A second way the government can raise more money is through additional debt issues.

The government can either default on its existing debt at the beginning of the period or decide to pay it back. If it defaults on its debt, the debt is written off but credit markets are disrupted and the country cannot borrow again until next period when it will be ruled by the next government. If the first period government does not default, it can borrow an amount $D_{1}$ that is payable at date 2 by the second period government. The first period government uses the proceeds of the new debt issued, as well as the taxes raised, to make committed debt repayments as well as to fund its spending.

We assume new debt $D_{1}$ is in the form of own-currency bearer bonds. Because the second period government cannot tell domestic investors from foreign investors, it cannot default selectively. Let the amount foreign investors buy be denoted as $D_{1}^{F o r}$ and the amount domestic investors buy be $D_{1}^{\text {Dom }}$ with $D_{1}=D_{1}^{\text {For }}+D_{1}^{\text {Dom }}$. We assume that there is no cost of defaulting on government debt held by foreigners, other than that of disrupting the credit markets and postponing any new borrowing to next period. There is, however, a cost to the second period government of defaulting on domestically held government debt which, in reduced form, results in the government spending $z D_{1}^{\text {Dom }}(1+r)$ less on populist measures, where $z>1$.

The deadweight cost of default $z$ reflects the centrality of low risk government bonds to the functioning of the domestic financial sector in a rich country. Rich country financial systems are typically more arm's length and market based, with the credit

\footnotetext{
${ }^{8}$ Equivalently, there is a uniform income tax, and the government levies an additional set of taxes such as payroll taxes or excise duties on real investment projects. Financial investments are typically subject to lower taxation, partly because of their greater mobility in a country with an open capital account.
} 
worthiness of financial sector participants of critical importance in supporting the high transaction volume. Any hint that any of the players could be impaired as a result of losses on their holdings of government assets could lead to questions about their creditworthiness, and a dramatic fall in financial activity and hence economic output (see, for example, Gennaioli, Martin and Rossi (2011)). For any given size of government bonds held by the financial sector, the cost of government default could be higher in rich countries because more transactions are disrupted. Another channel could be that government bonds are collateral (see Bolton and Jeanne (2011)) for many transactions where even the slight hint of default risks could make transaction costs prohibitive. Again, many more such transactions are likely to take place in a rich country's financial system.

Of course, a plausible argument could be made for $z$ being higher in underdeveloped, repressed financial sectors, where financial institutions may be forced to hold disproportionate amounts of government debt because few other buyers can be found. In our framework, though, borders are open, so enforcement mechanisms have to be very sophisticated for repression to be effective. This would again suggest $z$, if anything, is higher in more sophisticated financial systems where repressive regulations can be enforced.

We will allow the deadweight cost $z$ to be endogenously determined later in the paper. It may be pushed higher if the government opens new markets for collateralized borrowing, or if the government mandates a higher liquidity holding of government bonds by domestic banks. The timeline of the model is in Figure 1. 
Figure 1: Model timeline

\begin{tabular}{|c|c|c|c|c|c|}
\hline Period 1 & & & & Period 2 & \\
\hline $\mathrm{t}=0$ & & $\mathrm{t}=1$ & & $\mathrm{t}=1^{+}$ & $t=2$ \\
\hline $\begin{array}{l}\text { (1) Existing } \\
\text { foreign debt } \\
D_{0} \text { and } \\
\text { corporate } \\
\text { endowment } \\
E_{0} .\end{array}$ & $\begin{array}{l}\text { (2) Govt } \\
\text { decides } \\
\text { whether to } \\
\text { announce } \\
\text { "default" on } \\
\text { legacy debt; } \\
\text { It announces } \\
\text { tax rate } t_{1} \text {; } \\
\text { Corporate } \\
\text { sector makes } \\
\text { investment } \\
k_{1} \text { and saves } \\
\text { the rest }\left(E_{0^{-}}\right. \\
\left.k_{1}\right)\end{array}$ & $\begin{array}{l}(3) \text { Short } \\
\text { run } \\
\text { corporate } \\
\text { output } f_{l}\left(k_{1}\right) \\
\text { realized; }\end{array}$ & $\begin{array}{l}\text { (4) Govt } \\
\text { collects taxes } \\
t_{1} f_{1}\left(k_{1}\right) \text {; } \\
\text { Govt repays } \\
\text { debt of } \\
D_{0}(1+r) \text { and } \\
\text { raises new } \\
\text { debt (if no } \\
\text { default): } \\
\text { Externally } \\
\text { financed debt } \\
\text { is } D_{1}^{\text {For }} \text {, } \\
\text { domestically } \\
\text { financed } \\
\text { debt } D_{1}^{\text {Dom }} \text {. }\end{array}$ & $\begin{array}{l}\text { (5) New govt } \\
\text { comes in; } \\
\text { Govt decides } \\
\text { whether to } \\
\text { announce } \\
\text { "default" on } \\
\text { legacy debt; } \\
\text { announces } \\
\text { tax rate } t_{2} ;\end{array}$ & $\begin{array}{l}\text { (6) Long run } \\
\text { corporate } \\
\text { output } f_{2}\left(k_{1}\right) \\
\text { realized; Govt } \\
\text { collects taxes } \\
t_{2} f_{2}\left(k_{1}\right) \text {; } \\
\text { Govt repays } \\
\text { debt of } \\
D_{1}(1+r) \\
\text { (if no default) }\end{array}$ \\
\hline
\end{tabular}

\section{Solving for Debt and Default}

Since date 2 is the last period, the second-period government cannot borrow, and will repay existing debt if the cost of default exceeds the funds repaid, that is if,

$$
D_{1}(1+r) \leq z D_{1}^{D o m}(1+r)
$$

This represents the country's willingness to pay. Since $D_{1}=D_{1}^{\text {For }}+D_{1}^{D o m}$, the willingness-to-pay constraint can also be expressed as a constraint on the foreign borrowing of the first-period government $D_{1}^{\text {For }} \leq(z-1) D_{1}^{D o m}$, which is why we require $z$ to be greater than 1 . 
Furthermore, at date 2, the second-period government will raise taxes to the maximum possible so that $t_{2}=t^{M a x}$. The government therefore has the ability to pay its debt if

$$
D_{1}(1+r) \leq t^{\operatorname{Max}} f_{2}\left(k_{1}\right)
$$

(1) and (2) are the key constraints in determining future debt capacity. Now let us fold back to date 1 when the first period government has to choose whether to default or not on initial debt $D_{0}$, the tax rate $t_{1}$, and the amount of debt it will borrow, $D_{1}$, if it has not defaulted.

\subsection{Corporate Investment and First Period Government's Maximization Problem}

Start first with the private sector's investment incentives. Corporations maximize the present value of their post-tax cash flows net of the cost of investment, discounted at the opportunity rate from lending in the bond market:

$$
\max _{k_{1}} \frac{1}{(1+r)}\left(1-t_{1}\right) f_{1}\left(k_{1}\right)+\frac{1}{(1+r)^{2}}\left(1-t_{2}\right) f_{2}\left(k_{1}\right)-k_{1} \text {. }
$$

Clearly $k_{1} \leq E_{0}$ for external borrowing to be feasible (external borrowing is infeasible if there is no domestically-held government debt going into the last date, and a positive level of domestically-held government debt requires domestic private sector financial savings, so $k_{1}<E_{0}$ ). Assume the inequality holds. Then, the first-order condition for corporate investment satisfies

$$
\frac{1}{(1+r)}\left(1-t_{1}\right) f_{1}^{\prime}\left(k_{1}\right)+\frac{1}{(1+r)^{2}}\left(1-t_{2}\right) f_{2}^{\prime}\left(k_{1}\right)-1=0
$$


We denote the solution to (4) as $k_{1}^{*}\left(t_{1}, t_{2}\right)$. Corporate investment $k_{1}^{*}\left(t_{1}, t_{2}\right)$ obviously decreases in the level of tax rates $t_{1}$ and $t_{2}$. Since $t_{2}=t^{M a x}$ throughout, in what follows we adopt the simpler notation $k_{1}^{*}\left(t_{1}\right)$.

Now consider the myopic government's objective of maximizing spending. If it does not intend to default, it will solve

$$
\max _{D_{1}, t_{1}} D_{1}-D_{0}(1+r)+t_{1} f_{1}\left(k_{1}^{*}\left(t_{1}\right)\right)
$$

subject to constraints (1) and (2).

If the government does intend to default on its debt, it expects to be shut out from the debt market and will maximize

$$
\max _{t_{1}} t_{1} f_{1}\left(k_{1}^{*}\left(t_{1}\right)\right)
$$

We first assume no default, then the case with default, and compare the two to determine the default decision.

\subsection{No default by first-period government}

Clearly, assuming they do not expect default, government debt bought by domestic investors in the first period will equal domestic private savings (given their mild home bias, they do not invest abroad if expected returns are equalized), so $D_{1}^{\text {Dom }}=\left(E_{0}-k_{1}\right) .{ }^{9}$ Substituting into the willingness-to-pay constraint, we get $D_{1} \leq z\left(E_{0}-k_{1}^{*}\left(t_{1}\right)\right)$

Now, consider the government's decision. Since the government derives benefits from spending, it wishes to borrow as much as possible until one of the two constraints

\footnotetext{
${ }^{9} \mathrm{We}$ assume that the transition from poverty to middle income is defined by the condition $E_{0}>k_{1}$ so financial savings of the private sector are positive.
} 
binds. Depending upon which constraint binds first, the remaining part of the program choosing the tax rate - can be analyzed separately under each constraint. Before we analyze each case separately, we consider which constraint - ability to pay or willingness to pay - binds and when.

\section{Constrained by ability to pay or willingness to pay?}

As the first-period tax rate $\left(t_{1}\right)$ is varied, the ability-to-pay constraint binds before willingness-to-pay constraint if and only if

$$
\frac{1}{(1+r)} t_{2} f_{2}\left(k_{1}^{*}\left(t_{1}\right)\right) \leq z\left(E_{0}-k_{1}^{*}\left(t_{1}\right)\right) \text {. }
$$

Given that $k^{*}$ decreases in $t_{1}$, we have

Lemma 1: There exists a level of corporate tax rate in the first period, $\overline{t_{1}}$, such that only

the ability-to-pay constraint binds if $t_{1}>\bar{t}_{1}$ and only the willingness-to-pay constraint

binds if $t_{1}<\bar{t}_{1}$. The threshold level $\overline{t_{1}}$ is decreasing in the starting endowment $E_{0}$ and deadweight cost of default $z$.

The intuition is straightforward. As the corporate tax rate rises, investment falls, reducing the next government's tax proceeds. Simultaneously, domestic savings increase, allowing government domestic borrowing to increase, increasing the deadweight costs suffered by next government from defaulting on sovereign debt, and increasing the willingness to pay. Thus, at high corporate tax rates, it is the ability-to-pay constraint that binds. Conversely, at low tax rates, the willingness-to-pay constraint binds. 


\section{Binding Ability To Pay}

When the binding constraint is the ability to pay, the first-period government's maximization problem is given by

$$
\max _{t_{1}} \frac{1}{(1+r)} t_{2} f_{2}\left(k_{1}^{*}\left(t_{1}\right)\right)+t_{1} f_{1}\left(k_{1}^{*}\left(t_{1}\right)\right) \text {. }
$$

Effectively, the current government chooses the tax rate to maximize the proceeds of taxes in both periods since it can borrow against next period's tax proceeds by taking on debt and passing on the burden of repayment to the next government. The optimal tax, $t_{1}^{A}$, satisfies the first-order condition: ${ }^{10}$

$$
\left[\frac{1}{(1+r)} t_{2} f_{2}{ }^{\prime}\left(k_{1}^{*}\right)+t_{1} f_{1}^{\prime}\left(k_{1}^{*}\right)\right] \frac{d k_{1}^{*}}{d t_{1}}+f_{1}\left(k_{1}^{*}\right)=0 \text {. }
$$

Note that $\frac{d k_{1}^{*}}{d t_{1}}<0$ so that at low tax rates, proceeds increase in tax rate (the direct effect of a higher marginal tax rate), but if the tax rate becomes very large, the indirect effects as it reduces corporate investment dominate - the standard Laffer Curve effect. With standard concavity of the optimization problem we have Lemma 2: In the region where only the ability-to-pay constraint binds, the first-period government's optimal tax rate is given by $t_{1}^{A}$, which solves (9), and is unaffected by the starting endowment $E_{0}$ and deadweight cost of default $z$.

${ }^{10}$ A sufficient condition to ensure the second-order condition is negative is that $\frac{d^{2} k_{1}^{*}}{d t_{1}^{2}}<0$. Using condition (4), this is always met when $f_{1}^{\prime \prime \prime}<0, f_{2}^{\prime \prime \prime}<0$. 
Next, we consider the solution when the willingness to pay is the binding constraint.

\section{Optimal Taxes and Borrowing in the Willingness-to-pay Region}

In this case, the first-period government's problem is

$$
\max _{t_{1}} t_{1} f_{1}\left(k_{1}^{*}\left(t_{1}\right)\right)+z\left(E_{0}-k_{1}^{*}\left(t_{1}\right)\right)
$$

Now, the government's tax rate choice becomes interesting. It can no longer borrow fully against next government's tax revenues as the next government is constrained by its willingness to repay public debt. On the one hand, the current government may want to lower the tax rate to induce the corporate sector to invest more, thus allowing the taxable revenues to increase. This is the standard incentive effect of lower taxes. On the other hand, lowering the corporate tax rate shrinks the financial savings in the economy, shrinking the domestic appetite for government debt, reducing the next government's willingness to pay, and in turn the current government's ability to borrow. Put differently, the short-horizon government may want to "crowd out" private real investment (and economic growth) in an attempt to increase its short-term borrowing and spending capacity.

The optimal tax rate trades off these two effects. We denote the solution to this program as $t_{1}^{W}$ and it satisfies the first-order condition: ${ }^{11}$

$$
\left[-z+t_{1} f_{1}^{\prime}\left(k_{1}^{*}\right)\right] \frac{d k_{1}^{*}}{d t_{1}}+f_{1}\left(k_{1}^{*}\right)=0
$$

${ }^{11}$ Again, a sufficient condition to ensure the second-order condition is negative is that $\frac{d^{2} k_{1}^{*}}{d t_{1}^{2}}<0$ which is always met when $f_{1}^{\prime \prime \prime}<0, f_{2}^{\prime \prime \prime}<0$. 
Lemma 3: In the region where only the willingness-to-pay constraint binds, the firstperiod government's optimal tax rate $t_{1}^{W}$ satisfies (11), and is not affected by the starting endowment $E_{0}$, but is increasing in deadweight cost of default $z$.

\section{Optimal Taxes and New Borrowing}

Comparing the first-order condition in the willingness-to-pay region (11) with that in the ability-to-pay region (9), it follows that $t_{1}^{W}>t_{1}^{A}$. Combining the analysis, we have:

Proposition 1: Conditional on not defaulting, the first-period government chooses a tax rate $t_{1}^{*}$ where (i) $t_{1}^{*}=t_{1}^{A}$, if $t_{1}^{W} \geq t_{1}^{A}>\bar{t}_{1}$; (ii) $t_{1}^{*}=\bar{t}_{1}$, if $t_{1}^{W} \geq \bar{t}_{1} \geq t_{1}^{A}$; and, (iii) $t_{1}^{*}=t_{1}^{W}$ otherwise. Further, new government borrowing $D_{1}^{*}$ is given by the condition:

$$
D_{1}^{*}=\min \left[\frac{1}{(1+r)} t_{2} f_{2}\left(k_{1}^{*}\left(t_{1}^{*}\right)\right), z\left(E_{0}-k_{1}^{*}\left(t_{1}^{*}\right)\right)\right]
$$

where $k_{1}^{*}\left(t_{1}^{*}\right)$ satisfies (4) for $t_{1}=t_{1}^{*}$ and $t_{2}=t^{\text {Max }}$.

To understand the solution better, let us consider how it varies as we change the starting endowment $E_{0}$ and the sophistication of the financial sector $z$, which determines the deadweight cost of default. As Lemma 1 indicates, the threshold level $\bar{t}_{1}$ is decreasing in the starting endowment as well as the sophistication of the financial sector. We can show Corollary 1: If the starting endowment $E_{0}$ is sufficiently low, that is, below some threshold level $\underline{E}_{0}$, then the economy is in the willingness-to-pay region, $\bar{t}_{1}>t_{1}^{W} \geq t_{1}^{A}$ and as $E_{0}$ increases, neither the tax rate $t_{1}^{*}$ nor investment $k_{1}^{*}\left(t_{1}^{*}\right)$ increase. Government borrowing $D_{1}^{*}$, however, increases. As $E_{0}$ increases above the threshold $\underline{E}_{0}$ but is below a 
higher threshold $\overline{E_{0}}, t_{1}^{W} \geq \bar{t}_{1} \geq t_{1}^{A}$, and both constraints bind. The tax rate $t_{1}^{*}$ now falls as $E_{0}$ increases, and government borrowing continues to increase. Finally, when $E_{0}>\overline{E_{0}}$, the economy is in the ability-to-pay region, with $t_{1}^{W} \geq t_{1}^{A}>\bar{t}_{1}$. In this region again, as endowment $E_{0}$ increases, the tax rate $t_{1}^{*}$, investment $k_{1}^{*}\left(t_{1}^{*}\right)$, and government borrowing $D_{1}^{*}$ all remain unaffected.

Consider a simple example that allows us to illustrate Proposition 1 and Corollary 1. Let $f_{1}(k)=\alpha \theta k^{\gamma}, f_{2}(k)=(1-\alpha) \theta k^{\gamma}$, where $\alpha \in(0,1), \theta>0, \gamma \in(0,1) .{ }^{12}$ Let $\alpha=0.75, \theta=3, \gamma=0.66, t^{\operatorname{Max}}=0.6, r=0.05, E_{0}=1.0, z=1.1$.

As Figure 2 suggests, optimal tax rates (assuming no default for now), given by $t_{1}^{*}$, decrease in the endowment for intermediate values of the endowment (when both constraints bind simultaneously); Additional endowments increase willingness to pay, so tax rates have to fall for the economy's ability to pay to keep pace. However, the relationship is flat both for very high and very low levels of endowment. This is because the optimal tax when only one of the constraints binds is independent of endowments. ${ }^{13}$

As Figure 3 suggests, new government borrowing $D_{1}^{*}$ increases for low and moderate levels of endowment when the binding constraint is the ability to pay, and the marginal addition to endowment goes into the domestic debt market, thus expanding debt capacity. However, there is no effect on debt at high levels of endowment - for countries

\footnotetext{
${ }^{12}$ Closed form expressions for the example are in the appendix B.

${ }^{13}$ Note that at very low levels of endowment, the unconstrained optimal tax rate $t_{1}^{W}$ exceeds $t^{\operatorname{Max}}$ so that $t_{1}^{*}$ is truncated at $t^{\operatorname{Max}}$.
} 
with large endowments, debt is capped by their ability to pay, which is not affected at the margin by the additional endowments going into the domestic debt market.

In Figures 4 and 5, instead of varying endowment, we vary the productivity parameter $\theta$. At low productivity levels, the economy's ability to pay is the constraint, whereas at high productivity levels, its willingness to pay is the constraint. In the region where both bind, the optimal tax increases in productivity - higher productivity means more goes to real investment, which means higher taxes are needed for funds to flow to the financial sector.

Less intuitive is that $D_{1}^{*}$ is non-monotone in productivity (see Figure 5), rising initially and falling eventually. That new government borrowing rises with productivity in the ability-to-pay region is natural given that the more productive private sector will produce greater cash flows in the future, which alleviates the constraint. In the willingness-to-pay region, however, the short-horizon government has to tax harshly so as to boost domestic financial savings. When productivity is high, the required tax rate to maintain a commensurate willingness to pay can be substantial, and debt capacity $D_{1}^{*}$ can fall with productivity.

We can also characterize what happens as the parameter $z$ representing the deadweight cost of default varies.

Corollary 2: If the deadweight cost parameter $z$ is sufficiently low, that is, below some threshold level $\underline{z}$, then the economy is in the willingness-to-pay region and as z increases, government borrowing $D_{1}^{*}$ and the tax rate $t_{1}^{*}$ increase, whereas investment $k_{1}^{*}\left(t_{1}^{*}\right)$ decreases. As zincreases above the threshold z $\underline{b}$ but is below a higher threshold $\bar{z}$, 
$t_{1}^{W}>\bar{t}_{1}>t_{1}^{A}$, and both constraints bind. The tax rate $t_{1}^{*}$ now falls as $z$ increases, and

government borrowing continues to increase. Finally, if z increases over the threshold $\bar{z}$, then the economy is in the ability-to-pay region. In this region, as z increases, government borrowing $D_{1}^{*}$, the tax rate $t_{1}^{*}$ and investment $k_{1}^{*}\left(t_{1}^{*}\right)$ remain constant.

Interestingly, the relationship between the deadweight cost parameter and the tax rate is non-monotonic, reflecting the effects of differing binding constraints. In particular, in the region where the willingness to pay binds, an increase in $z$ increases the ability of the government to borrow the amounts that go into financial savings, giving it a greater incentive to tax real corporate investment. This could be thought of as a form of “economic repression”.

The remaining step is to analyze when the first-period government chooses to default versus repaying the legacy debt. We turn to that now.

\subsection{No-default level of legacy debt}

In case the government chooses to default, it is shut out from the debt markets. Its total resources available for spending come only from tax collection but it is free from repaying the debt of the past. Therefore, conditional on default, it chooses $t_{1}$ to solve

$$
\max _{t_{1}} t_{1} f_{1}\left(k_{1}^{*}\left(t_{1}\right)\right)
$$

The solution to this problem is denoted as $t_{1}^{* *}$ and it satisfies the first-order condition:

$$
t_{1} f_{1}^{\prime}\left(k_{1}^{*}\right) \frac{d k_{1}^{*}}{d t_{1}}+f_{1}\left(k_{1}^{*}\right)=0
$$


Note the tax rate conditional on an intent to default is in between the low tax rate when the government wants to enhance the future government's ability to pay debt, and the higher tax rate if it wants to enhance the future government's willingness to pay debt. The first-period government defaults if and only if

$$
t_{1}^{* *} f_{1}\left(k_{1}^{*}\left(t_{1}^{* * *}\right) \geq D_{1}^{*}-D_{0}(1+r)+t_{1}^{*} f_{1}\left(k_{1}^{*}\left(t_{1}^{*}\right)\right) .\right.
$$

Thus, we obtain:

Proposition 2: There is a threshold level of date-0 (legacy) debt $D_{0}^{\text {Max }}$ such that the firstperiod government defaults on this debt if and only if $D_{0} \geq D_{0}^{\text {Max }}$, where $D_{0}^{\text {Max }}$ is the value of $D_{0}$ that equates both sides of (15), and where in turn $D_{1}^{*}$ and $t_{1}^{*}$ are as described in Proposition 1, $t_{1}^{* * *}$ satisfies (14), and $k_{1}^{*}\left(t_{1}\right)$ solves (4). The no-default level of legacy debt $D_{0}^{\text {Max }}$ is increasing in the initial endowment $E_{0}$ and the deadweight cost of default, $z$.

In other words, we obtain the natural result that short-horizon governments are more likely to default following an adverse endowment shock, which reduces the willingness to pay of successor governments, and hence the ability to borrow today. Similarly, they are also more likely to default if the likely damage to the domestic financial sector from a future default is smaller, constraining their ability to borrow today.

We plot $D_{0}^{M a x}$ for different values of endowment in Figure 3 and for different values of productivity in Figure 5. $D_{0}^{\text {Max }}$ is always weakly below $D_{1}^{*}$, suggesting the government finds deviations from the short-term revenue-maximizing tax rate to enhance debt capacity worthwhile only if it produces a net inflow from the debt markets. $D_{0}^{\operatorname{Max}}$ is 
equal to $D_{1}^{*}$ only when parameters are such that the government selects the short-term revenue-maximizing tax rate even when it is trying to maximize $D_{1}^{*}$. Finally, as with debt capacity $D_{1}^{*}$, the default point $D_{0}^{\operatorname{Max}}$ is also increasing in endowments but non-monotone (first increasing and then decreasing) in private sector's productivity. We also plot the tax rate $t_{1}^{* * *}$ that the short-term government charges if it defaults on legacy debt. This tax rate is invariant in endowment (Figure 2) and productivity (Figure 4), and lies in between the tax rates charged absent default at the extreme values of endowment and productivity.

\section{Debt and Default with a Long Horizon Government}

Let us now compare the short-horizon government's decision to default with that of a long-horizon government, which cares about spending in both periods. Interestingly, a long-horizon government would default more, that is, over a greater parameter range than a short-horizon government. The reason is that the myopic government does not internalize the cost of the future repayment of current borrowing, and in the willingnessto-pay region, also the distortion caused by current taxation (which tries to maximize current resources including borrowing) on future output and tax revenues. The longhorizon government internalizes these costs and therefore does not find borrowing to repay old debt as attractive. It is more willing to default on legacy debt so as to restore economy's long-run growth prospects. 


\subsection{Variable Horizon}

Formally, suppose the government discounts the future using factor $\beta \in\left[0, \frac{1}{1+r}\right]$. When $\beta=0$, we have our short-horizon government, while when $\beta=\frac{1}{1+r}$, we have a longhorizon government which has the same rate of time preference as the market. In between, we have differing degrees of myopia. The government's objective function if it borrows to repay existing debt and spends the rest, is given by

$$
\left[D_{1}-D_{0}(1+r)\right]-\beta D_{1}(1+r)+t_{1} f_{1}\left(k_{1}\left(t_{1}\right)\right)+\beta t_{2} f_{2}\left(k_{1}\left(t_{1}\right)\right)
$$

By inspection, if $\beta=\frac{1}{(1+r)}$, then a long-horizon government sees no benefit in bringing forward spending by borrowing, since that cuts into future spending. So it gets no benefit from having continued access to debt markets. As a result, it does not want to repay the legacy debt, and will always default. Now let us turn to see what happens at lower levels of $\beta$. We will show that the amount of legacy debt it is willing to service falls in $\beta$.

When the government's borrowing is constrained by its ability to pay, it can borrow up to second period revenues, so $D_{1}=\frac{t_{2} f_{2}}{1+r}$. Substituting in (16), the government's maximization simplifies to (8), which is just the short-horizon government's problem. So $t_{1}^{A, \beta=0}=t_{1}^{A, \beta>0}$. This should not be surprising because, as we noted earlier, the ability to borrow in the debt markets effectively lengthens the shorthorizon government's horizon, and makes it fully internalize long-term revenue when ability to pay is the constraint. 
However, the government's objective function when only the willingness to pay constraint binds is not the same as that of the short-horizon government. In that region, $D_{1}=z\left(E_{0}-k_{1}^{*}\left(t_{1}\right)\right)$. Substituting in (16) and differentiating w.r.t. $t_{1}$, we get

$$
\left[-z+t_{1} f_{1}^{\prime}\left(k_{1}^{*}\right)+z \beta(1+r)+\beta t_{2} f_{2}^{\prime}\left(k_{1}^{*}\right)\right] \frac{d k_{1}^{*}}{d t_{1}}+f_{1}\left(k_{1}^{*}\right)=0 .
$$

Comparing with (11), we see that $t_{1}^{W, \beta=0}>t_{1}^{W, \beta>0}$. Moreover, differentiating w.r.t. $\beta$ and using the envelope theorem, we see that $\frac{d t_{1}^{W, \beta>0}}{d \beta}<0$; As the government cares more about the future, the tax rate it sets in the willingness-to-pay region falls. This is because it internalizes to a greater extent the distortions stemming from the higher tax rate needed to move resources into the financial sector so as to ensure greater willingness to pay for future governments. Note also that $\overline{t_{1}}$, which is the tax rate demarcating the boundary between the willingness to pay region and the ability to pay region, does not vary with $\beta$. This means that as $\beta$ rises, the government moves from not being constrained by the willingness to pay to being constrained by the willingness to pay.

Finally, if the government decides to default, it sets $t_{1}$ to maximize

$$
G \equiv t_{1} f_{1}\left(k_{1}\left(t_{1}\right)\right)+\beta t_{2} f_{2}\left(k_{1}\left(t_{1}\right)\right) .
$$

Let $t_{1}^{* * *}$ be the solution. Then the government will not default iff $G\left(t_{1}^{* * *}\right) \leq D_{1}^{*}-D_{0}(1+r)-\beta D_{1}^{*}(1+r)+G\left(t_{1}^{*}\right)$ where $D_{1}^{*}$ is the maximum amount of debt it can borrow at date 1 . This means the maximal legacy debt that will be repaid is

$$
D_{0}^{M a x}=\frac{1}{(1+r)}\left[D_{1}^{*}(1-\beta(1+r))+G\left(t_{1}^{*}\right)-G\left(t_{1}^{* * *}\right)\right]
$$

Differentiating w.r.t. $\beta$, we get after some algebra: 
Proposition 3: As the government's discount factor Bincreases, the maximum legacy

debt $D_{0}{ }^{\text {Max }}$ it is willing to repay falls. When $\beta=\frac{1}{1+r}$, the government is not willing to repay any legacy debt, that is, $D_{0}{ }^{\text {Max }}=0$.

Therefore lengthening horizons reduces the attractiveness of repaying legacy debt at date 0 . The sole benefit to repayment is the ability to borrow again. But with longer horizons, new borrowing is less attractive because, first, the government internalizes to a greater extent the future costs of repaying new debt, and, second, the maximum amount of new debt it is willing to raise is also lower because the government internalizes the costs to future revenues from setting the higher tax rate today that is needed to signal its willingness to pay. Therefore, by making future borrowing less attractive, and therefore default more attractive, longer horizons reduce the first period government's debt capacity (and of governments before it). By contrast, a short-horizon government will not default because it values the benefits from immediate expenditures while disregarding the costs of new borrowing and lower future revenues, which largely fall on future governments.

Figures $6 \mathrm{a}$ and $6 \mathrm{~b}$ illustrate for the parameters in our example how tax policy and debt capacity behave as a function of $\beta$, the inverse of government myopia, as endowment is varied. Figures $7 \mathrm{a}$ and $7 \mathrm{~b}$ repeat the exercise as private sector's productivity is varied. As $\beta$ rises, the government becomes more long-horizon in its 
decision-making. Its optimal tax rate given no default falls (so does its borrowing $D_{1}^{*}$ in this case) and the maximum amount of legacy debt it will pay, $D_{0}^{\text {Max }}$, falls as well. ${ }^{14}$

\subsection{Valuable Government Spending and the Benefits of Short Horizons}

Note that without any economic role for government spending, even the longhorizon government's taxation policy is suboptimal relative to the first-best, which is simply to have no taxes whatsoever. This, however, is again just for simplicity and our qualitative comparisons would hold even if we added a multiplier on government spending. Specifically, suppose government spending yields value that is $m$ times the spending. Then, the objective function of the government (no matter of what type) does not change since all spending is multiplied by $m$. However, when $m$ is greater than one but not too large, some government spending is efficient, and its level is obtained by equating the marginal return of private sector's capital investment to the multiplier on government spending. ${ }^{15}$

If some government spending is efficient, then a government could benefit its country by generating some additional debt capacity. Note that a short horizon government can generate more debt capacity than a long horizon government, simply because the former does not internalize the cost of repaying the debt, and therefore can commit to servicing it. Somewhat paradoxically then, the long horizon government may be unable to undertake valuable ex-ante spending precisely because its concerns about the

\footnotetext{
${ }^{14}$ Note that two of the cases, $\beta=0,0.25$ correspond to identical outcomes in Figures $6 \mathrm{a}$ and $7 \mathrm{a}$.

${ }^{15}$ When the multiplier is sufficiently large, it may be first-best efficient to have all spending be done by the government rather than some real investments being made by the private sector. If the multiplier is not too large, the private sector equates the present value of the after tax cash flows on the marginal dollar invested to 1 . This achieves the first best when the tax rate is the same across periods and set at $\frac{1}{1-t}=m$. So long as $m>1$, the first-best tax rate $t>0$ and some government spending is efficient in the first-best outcome.
} 
ex-post distortions entailed in repaying such spending make lenders distrust it. The expost distortions may, however, be smaller than the ex-ante benefit, in which case short horizons may be beneficial.

Finally, to the extent that democratic governments have shorter horizons than more authoritarian governments, a switch from democracy to autocracy reduces a country's debt capacity and increases the risk associated with its outstanding debt. In other words, political risk associated with an increase in authoritarianism could be very detrimental to debt values.

\section{Endogenous choice of financial sophistication}

Thus far, we have taken the deadweight cost of defaulting on domestically held government debt, $z$, as given. Governments do have some freedom in choosing $z$, for instance, pushing it higher by encouraging a repo market in government assets.

A good example of creating a class of debt that is so entangled with the financial sector's transactions that it is hard to default on is the "special" status accorded to the debt of government-sponsored enterprises (GSE), Fannie Mae and Freddie Mac, in the United States. A significant portion of the GSE debt is held by the financial sector and by foreign governments who trade it freely in a highly liquid and sophisticated market - the so-called "agency debt" market. Agency debt serves the role of collateral for open-market operations (OMO) with the Federal Reserve - equivalent to the role played by Treasuries, so that any default would disrupt the transactional services associated with this debt. ${ }^{16}$

\footnotetext{
${ }^{16}$ Further, default on GSE debt would not only impose collateral damage on the domestic financial sector, but also raise concerns about implications for repayment on Treasury debt: "They (foreign governments) wanted to know if the U.S. would stand behind the implicit guarantee - and what this would imply for other U.S. obligations, such as Treasury bonds." - Henry Paulson, the United States Treasury Secretary during Fall 2008, in his account of the crisis, On the Brink, Business Plus, 2010.
} 
Market participants could have reasonably concluded that the special treatment accorded GSE debt as OMO collateral and the associated centrality of the agency debt market indicated that the United States government would stand behind this debt in the final eventuality. This implicit guarantee, in turn, enabled the GSEs to borrow substantially despite being privately held enterprises. The implicit guarantee was indeed honored by the government when GSEs were placed in government "conservatorship" in September 2008, without debt holders suffering any losses. ${ }^{17}$

Once $z$ becomes a choice variable, willingness to pay is no longer a constraint on borrowing. However, with no uncertainty, governments cannot set a debt level at which they would default, for creditors would not agree to lend. Of course, so long as the government does not default at date 2 , the cost of default stemming from $z$ is never incurred. To make the choice of $z$ at date 0 interesting, we extend the model to allow for uncertainty in date- 2 output.

Specifically, suppose that with probability $q$, second-period output will be high at $f_{2}^{H}\left(k_{1}\right)>0$, and otherwise low at $f_{2}^{L}\left(k_{1}\right)=0, \forall k_{1}$. Hence, the private sector's problem can be restated as $\max _{k_{1}} \frac{1}{(1+r)}\left(1-t_{1}\right) f_{1}\left(k_{1}\right)+\frac{1}{(1+r)^{2}}\left(1-t_{2}\right) q f_{2}^{H}\left(k_{1}\right)-k_{1}$, and its optimized investment level $k_{1}^{*}$ is given by the modified first-order condition $\frac{1}{(1+r)}\left(1-t_{1}\right) f_{1}^{\prime}\left(k_{1}\right)+\frac{1}{(1+r)^{2}}\left(1-t_{2}\right) q f_{2}^{H^{\prime}}\left(k_{1}\right)-1=0$

Now, whenever debt is to be repaid in the second period, the country will default in the low state and incur the default costs from disruption of the domestic financial

\footnotetext{
${ }^{17}$ See Acharya, Nieuwerburgh, Richardson and White (2011), Chapter 4, for a detailed discussion.
} 
sector. Denoting the face value of newly issued debt as $D_{1}$ (so that its market value is $q D_{1}$ ), the government's problem is $\max _{t_{1}, z, D_{1}}\left[q D_{1}-D_{0}(1+r)\right]-\beta q D_{1}(1+r)-\beta(1-q) z D_{1}^{D o m}(1+r)+t_{1} f_{1}\left(k_{1}\left(t_{1}\right)\right)+\beta q t_{2} f_{2}^{H}\left(k_{1}\left(t_{1}\right)\right)$

subject to the constraints

$$
D_{1}(1+r) \leq \min \left[t_{2} f_{2}^{H}, z D_{1}^{\text {Dom }}(1+r)\right]
$$

and

$$
D_{1}^{\text {Dom }} \leq\left[E_{0}-k_{1}\left(t_{1}\right)\right]
$$

Since there is no reason to set the deadweight losses higher than what is needed to enforce maximum debt repayment, $D_{1}=z D_{1}^{D o m}$. Substituting in the objective function, it is clear it is increasing in $z D_{1}^{D o m}$ iff $\beta \leq \frac{q}{1+r}$. This then means setting $z$ such that $D_{1}=z D_{1}^{D o m}=\frac{t_{2} f_{2}^{H}}{1+r}$.

Substituting for $z D_{1}^{D o m}, D_{1}$ in the objective function, differentiating w.r.t. $t_{1}$ and collecting terms, we obtain the first-order condition with respect to $t_{1}$ as $\left[\left(\frac{q}{1+r}-\beta(1-q)\right) t_{2} f_{2}^{H^{\prime}}+t_{1} f_{1}^{\prime}\right] \frac{d k_{1}^{*}}{d t_{1}}+f_{1}=0$. Using the envelope theorem, and knowing that $D_{1}=\frac{t_{2} f_{2}^{H}}{1+r}, D_{1}^{D o m}=\left[E_{0}-k_{1}^{*}\left(t_{1}\right)\right]$, and $z^{*}=\frac{t_{2} f_{2}^{H}}{(1+r)\left[E_{0}-k_{1}^{*}\left(t_{1}\right)\right]}$, we can show Proposition 4: (i) $\frac{d t_{1}^{*}}{d \beta}>0, \frac{d D_{1}}{d \beta}<0, \frac{d z^{*}}{d \beta}<0$.

$$
\text { (ii) } \frac{d t_{1}^{*}}{d q}<0, \frac{d D_{1}}{d q}>0, \frac{d z^{*}}{d q}>0 \text {. }
$$


Interestingly, with $z$ endogenous, the optimal date- 1 tax increases as the government's horizon increases. This is because the expected cost to the government at date 2 - in terms of debt repayments and deadweight costs of default - exceeds the resources obtained from taxation at that date. Therefore, the higher the discount factor of the government, $\beta$, the less it wants to borrow. Because the only limit on borrowing is date- 2 production, the government lowers date- 2 production by raising the tax rate. It also reduces $z$ to match the lower value of debt payment that has to be committed to.

Conversely, the higher is $q$, the lower the probability the deadweight costs of default will be incurred, the higher the benefit to borrowing, and hence the lower the optimal date- 1 tax so as to expand investment, date- 2 production, and hence borrowing capacity. ${ }^{18}$ Similarly, the higher is $q$, higher is $z$ to ensure that the higher promised debt payment will be made.

More generally, the horizons of the government and the uncertainty affecting output both affect optimal debt and taxes. The more the government is myopic, the more it ignores the deadweight costs of default in the low state, and the higher the amount it wants to borrow. This implies lower taxes (to create future debt payment ability) and higher entanglement between the government and the financial sector so as to increase the future deadweight costs of default $z$. Less uncertainty again makes debt more attractive, and thus entails lower taxes today, and higher sophistication/entanglement.

\section{Implications}

The ongoing sovereign crisis in Europe raises some fundamental issues that our model can speak to. For instance, our model explains why some governments keep

\footnotetext{
${ }^{18}$ Note that $q$ also has the direct effect of making private sector's investment more attractive, all else equal, which also expands date- 2 production and therefore the borrowing capacity.
} 
current on their debt, even when most market participants suggest it would be better for them to default. So long as the Euro area and multilateral institutions are willing to provide funding to tide the country over, myopic governments really see no benefit in default, no matter how much debt accumulates. That does not, however, mean that servicing debt or taking actions that maintain or expand long term debt capacity (such as creating greater entanglements between domestic banks and domestic government debt) are optimal.

In this regard, the role of multilateral lending institutions has to be examined very carefully. Ostensibly, they lend to a country when private markets seize up, thus preventing the country from undergoing a wrenching real adjustment. The intent is that once private markets view the country more favorably - after real sector reforms shaped by conditions set by the multilateral institutions - the country will regain access to the private markets and repay its debt. Our model suggests that for developing countries, the key concern for the private markets is the time profile of the country's debt service burden and fears that the country will be required to make net debt repayments for a while that its myopic government will not honor. This means that left to its own devices, the country will not be able to regain access until its debt is rescheduled - though sometimes a minor rescheduling (see later) will be enough.

Multilateral lending institutions like the IMF can help sometimes, not just because they hold the carrot of additional loans, but because they can press the developing country government to cut unnecessary spending that will help put the country back on a sustainable (i.e., net positive debt inflows) debt path. Of course, IMF conditionality is 
onerous for governments, but they often fall behind program targets, reducing the effective cost.

For rich countries, though, the direct cost of default is substantial, and default looms only when the country simply does not have the political and economic ability to raise the revenues needed to repay debt - as, for example, in the case of Greece. When rich countries are in danger of default, outside agencies that lend them more without helping these countries expand productivity and growth are only postponing the inevitable messy restructuring. Rich country defaults are more likely to be solvency defaults rather than liquidity defaults, and a simple rescheduling of debt without significant haircuts to face value is unlikely to help the country regain access to private markets.

Another interesting development in the on-going sovereign debt crisis in Europe is the extreme degree of dependence of the health of a country's banking sector on the health of the government, and vice versa. Acharya, Drechsler and Schnabl (2010) document that the 91 European banks stress-tested in 2010 held sovereign bonds on average up to a sixth of their risk-weighted assets, and that within these sovereign bond holdings, there is a "home bias" in that banks held substantial portion in own government bonds. Indeed, the home bias in sovereign bond holdings was the highest for countries with the greatest risk of government debt default, ${ }^{19}$ suggesting they are positively correlated; Countries that are at greater risk of default also have banks whose portfolios are stuffed with own government debt.

\footnotetext{
${ }^{19}$ In particular, in the stress test data released by European regulators in April 2010, banks of Greece, Ireland, Portugal, Spain and Italy held on average more than sixty percent of their government bonds in own government bonds.
} 
One explanation is that banks are buyers of last resort (perhaps with some armtwisting) for their government's debt, and this is why risky countries, who find no other takers, stuff their banks with their paper. An alternative explanation (see Diamond and Rajan (2011)) is that banks have a natural advantage in loading up on risks that will materialize when they themselves are likely to be in default. But a third, not mutually exclusive, explanation is ours -- that countries have to prove to new bondholders their enduring resolve to service their foreign debt, and this is best done by making the costs of default on domestic debt prohibitively costly.

In this vein, consider the recent proposal of the Euro area think tank, Bruegel, for Euro area sovereigns to issue two kinds of debt, one (blue bond) that is guaranteed by all Euro area countries and will be held by domestic banks, and another (red bond) that is the responsibility of the issuing country only and which domestic banks will be prohibited from holding. Our model points out that there is very little reason for a country to service the red bonds. These will not be held by key domestic financial institutions, and therefore will not cause many ripples if they are defaulted on. This will make it hard for a country to borrow sizeable amounts through red bond issuances, which may indeed be the subtle intent of the proposal.

Let us now turn to other implications of our model. In our model, the costs of default are sizeable only when the country becomes rich (when it rarely defaults), but the costs of default (as well as the benefits) when it is developing are small. This may explain some curious aspects of defaults that are less easily explained by models that have high default costs no matter what the country's state of development. Specifically, in models where large penalties are triggered by default, the extent of the default typically should 
not matter (again see, for example, Eaton and Gersovitz (1981)). If so, the country might as well repudiate all its debt following the maxim “in for a penny, in for a pound". Yet countries rarely do this. ${ }^{20}$ At the same time, the existence of sizeable discrete default costs would imply that developing countries should not default only to reduce their debt a little - but debt renegotiations have ended with debtors agreeing to repay nearly 90 percent of present value of the outstanding debt (see the case of Uruguay's 2003 exchange described in Sturzenegger and Zettelmeyer (2005)).

Instead, the primary objective in debt renegotiations seems to be to find a mutually acceptable deal that will allow the country to regain access to the debt markets. In our model, following a default, a relatively small haircut in the face value of existing debt (or a rescheduling of maturities) could make the sequence of cash inflows from the external debt markets positive for each successive government until the country becomes rich and has a sizeable cost of default. The small haircut to existing debt would therefore be enough to make the debt sustainable. A greater haircut on the debt is not something the myopic government renegotiating a past default needs, nor is it likely to want to prolong its own exclusion from external capital markets in search of it, no matter what the future benefit to the country. Given the purpose of renegotiation is to regain debt market access with positive net inflows, the loss of market access can indeed be temporary, and debt haircuts very moderate. ${ }^{21}$

Our model also suggests a possible explanation for why external debt becomes shorter and shorter maturity as a country's economic difficulties mount. Clearly, lenders

\footnotetext{
${ }^{20}$ One could, of course, argue that the less that is repaid, the worse the type the country reveals itself to be.

${ }^{21}$ Tough negotiators, like the Argentinian government in the 2003-2005 debt negotiations, which till date of writing had yet to clear its arrears, are likely to be the exception, probably because their horizons are longer or because there is domestic political gain (that we do not model) to forcing large haircuts on unpopular foreign debt holders.
} 
want the ability to refuse to roll over their money if they see fundamental conditions deteriorating. But the key condition they could be monitoring is not the underlying country fundamentals but whether others are continuing to lend, giving the country an incentive to service debt - country liquidity and continuing debt service could be closely tied. So long as inflows are positive, the country will continue to service debt, and shortterm lending can be quite lucrative. The key is to stop lending before others are anticipated to stop, which is why a country's access can become quite fragile, and prone to multiple equilibria, as its fundamentals deteriorate and maturities shorten. "Sudden stops" in lending, and subsequent country default, are the natural consequence (though their full modeling is beyond the scope of our model).

\section{Related literature}

There is a vast literature on sovereign debt that we do not have the space to do justice to (see Eaton and Fernandez (1995) or Tomsz (2007) for excellent discussions). Our work is most closely related to the recent literature explaining why countries repay because of the costs to the domestic financial sector of sovereign defaults. Our contribution to this literature is to explain why developing countries service debt even though the costs of default to them are small. Government myopia plays a key role in the explanation, as well as in determining fiscal policy and debt capacity.

Broner, Martin, and Ventura (2010) assume the costs of default on domestic bond holders and argue that the ability of foreigners who hold domestic bonds to sell out surreptitiously to domestic entities in the secondary debt markets ensures that the government will never be able to default selectively on foreigners. Thus the costs of 
defaulting on domestically held bonds, combined with liquid and anonymous secondary markets, ensures the sustainability of foreign borrowing.

Gennaioli, Martin, and Rossi (2011) build a model in which banks demand government bonds as a store of liquidity. This then allows banks to expand intermediation, investment, and output of the economy. Governments can increase domestic wealth by defaulting on external creditors, but the disruption of the domestic financial sector reduces this incentive. Thus, financial development in their setup, which boosts the leverage of banks, increases the government's cost of default. They also provide empirical support for the implications of the model concerning the complementarity of public and private borrowing in good times, and the severe disruptions to credit and output following sovereign defaults in countries with financially developed markets.

Bolton and Jeanne (2011) consider a setting in which governments want to maintain their credit quality so as to keep the inter-bank market working - government bonds serve a useful collateral role, and banks wish to hold government bonds of different countries for diversification reasons. While these forces allow the possibility for governments to borrow ex ante, the financial integration across countries leads ex post to contagion. Since the costs of contagion are not fully internalized by governments of weaker countries, there may be an inefficient equilibrium supply of government debt.

Acharya, Drechsler and Schnabl (2010) consider the incentives of a long-horizon government to default on legacy debt when faced with the prospect of bailing out its distressed financial sector. Being long-horizon, their government internalizes the underinvestment induced in the private sector by excessive sovereign borrowing (and future 
taxation), a force that pushes it in the direction of default on legacy debt. However, the government is deterred by the potential collateral damage from sovereign default to the financial sector due to its government bond holdings and implicit guarantees. ${ }^{22}$

Finally, while we have argued that our paper offers an alternative lens to reputational models such as Tomsz (2007) through which to see sovereign debt, the two are not mutually exclusive. While we emphasize the short term outlook of governments and reputational models emphasize the reputational concerns of far-sighted governments, in reality most governments contain both short-term focused ministers as well as politicians who look to the long term. Whose influence is maximal, and when, will determine the kinds of behavior that one might see. More work is needed to nest the models and derive more detailed implications.

\section{Conclusion}

In this paper, we develop a model where myopic governments seek electoral popularity but can nevertheless commit credibly to service external debt. They do not default when they are poor because they would lose access to debt markets and be forced to reduce spending; they do not default when they become rich because of the adverse consequences to the domestic financial sector. Interestingly, the more myopic a government, the greater the advantage it sees in borrowing, and therefore the less likely it will be to default (in contrast to models where sovereigns repay because they are concerned about their long term reputation). More myopic governments are also likely to

\footnotetext{
${ }^{22}$ Acharya, Drechsler and Schnabl (2010) also employ data on credit default swaps (CDS) on banks and sovereigns during the period 2007-2010 and show evidence of what they call "the two-way feedback": While bailouts transferred risks from the financial sector to sovereign balance-sheets in the Fall of 2008, the steady deterioration of sovereign health since then has in turn contributed to widening of bank CDS.
} 
tax in a more distortionary way, and create more dependencies between the domestic financial sector and government debt that raise the costs of default. We use the model to explain recent experiences in sovereign debt markets.

\section{References}

Acharya, Viral V., Itamar Drechsler and Philipp Schnabl, 2010, A Pyrrhic Victory? Bank Bailouts and Sovereign Credit Risk, Working Paper, NYU Stern.

Acharya, Viral V., Stijn van Nieuwerburgh, Matthew Richardson and Lawrence White, 2011, Guaranteed to Fail: Fannie Mae, Freddie Mac and the Debacle of Mortgage Finance, Princeton University Press.

Aguiar, Mark and Manuel Amador, "Growth in the Shadow of Expropriation," NBER Working Papers 15194, National Bureau of Economic Research.

Arellano, Cristina, 2008, Default risk and income fluctuations in emerging economies, American Economic Review 98, 690-712.

Basu, Suman, 2009, Sovereign debt and domestic economic fragility, mimeo, MIT.

Bolton, Patrick, and Olivier Jeanne, 2011, Sovereign default and bank fragility in financially integrated economies, NBER working paper 16899.

Broner, Fernando, Alberto Martin and Jaume Ventura, 2010, Sovereign risk and secondary markets, American Economic Review 100, 1523-1555.

Bulow, Jeremy, and Kenneth Rogoff. 1989a. "A Constant Recontracting Model of Sovereign Debt.” Journal of Political Economy, 97(1): 155-78.

Bulow, Jeremy, and Kenneth Rogoff. 1989b. "Sovereign Debt: Is to Forgive to Forget?” American Economic Review, 79(1): 43-50.

Cole, H. and P. Kehoe (1998), "Models of Sovereign Debt: Partial vs. General Reputations", International Economic Review, 39, 55-70.

Diamond, Douglas and Raghuram G Rajan, 2011, Fear of Fire Sales and the Credit Freeze, Quarterly Journal of Economics, 126(2), 557-591.

Eaton, Jonathan and Raquel Fernandez, 1995, Sovereign debt, in G. Grossman and K. Rogoff (eds.), Handbook of International Economics III, Elsevier, North-Holland. 
Eaton, Jonathan and Mark Gersovitz, 1981, Debt with potential repudiation: Theoretical and empirical analysis, Review of Economic Studies 48, 284-309.

Eichengreen, B. (1987), "Til Debt do us Part: The U.S. Capital Market and Foreign Lending, 1920-1955” (NBER Working Paper No. 2394).

Fernández, Raquel, and Robert W. Rosenthal. 1990. "Strategic Models of SovereignDebt Renegotiations." Review of Economic Studies, 57(3): 331-49.

Flandreau, Marc, and Frederic Zumer, 2004, The Making of Global Finance 1880-1913, Paris: OECD.

Gennaioli, Nicola, Alberto Martin, and Stefano Rossi. 2011. "Sovereign Defaults, Domestic Banks, and Financial Institutions.” http://crei.cat/people/gennaioli.

Guembel, Alexander, and Oren Sussman, 2009, Sovereign debt without default penalties, Review of Economic Studies 76, 1297-3120.

Holmström, Bengt, 1999, "Managerial Incentive Problems: A Dynamic Perspective" The Review of Economic Studies Vol. 66, No. 1, Special Issue: Contracts (Jan., 1999), pp. 169-182

Kletzer, K. M. and B. D. Wright (2000), “Sovereign Debt as Intertemporal Barter", American Economic Review, 90, 621-639.

Levy-Yeyati, Eduardo and Ugo Panizza, 2006, "The Elusive Costs of Sovereign Defaults" (Inter-American Development Bank Research Department Working Paper \#581, November 2006);

Ozler, Sule, (1993), "Have Commercial Banks Ignored History?", American Economic Review 83, no 3, 608-620.

Prasad, Eswar, Raghuram Rajan and Arvind Subramanian, "Foreign Capital and Economic Growth”, Brookings Papers on Economic Activity, 2007 (1), 153-230.

Reinhart, Carmen M. and Kenneth S. Rogoff, 2009a, This Time Is Different: Eight Centuries of Financial Folly, Princeton University Press.

Reinhart, Carmen M. and Kenneth S. Rogoff, 2009b, "Growth in a Time of Debt", American Economic Review Papers and Proceedings, forthcoming.

Sandleris, Guido, 2009, Sovereign defaults, domestic credit market institutions and credit to the private sector, UTDT mimeo. 
Sandleris, Guido, Gaston Gelos, and Ratna Sahay. 2004. "Sovereign Borrowing by Developing Countries: What Determines Market Access?" International Monetary Fund Working Paper 04/221.

Sturzenegger, Federico and Jeromin Zettelmeyer, "Haircuts: Estimating Investor Losses in Sovereign Debt Restructurings, 1998-2005" (International Monetary Fund Working Paper, July 2005);

Tomz, Michael. 2007. Reputation and International Cooperation: Sovereign Debt across Three Centuries. Princeton, NJ: Princeton University Press.

\section{Appendix A: Proofs}

Lemma 1: Consider condition (7). Consider the difference between left hand and right

hand sides given by $\frac{1}{(1+r)} t_{2} f_{2}\left(k_{1}^{*}\left(t_{1}\right)\right)-z\left(E_{0}-k_{1}^{*}\left(t_{1}\right)\right)$. Since $f_{2}^{\prime}>0$ and $\frac{d k_{1}^{*}}{d t_{1}}<0$, it

follows that this difference is a decreasing function of $t_{1}$. Thus, (assuming interior

solutions) there exists a threshold tax rate $\bar{t}_{1}$ above which ability-to-pay constraint applies and below which willingness-to-pay constraint applies, and the threshold is given by the condition

$$
\frac{1}{(1+r)} t_{2} f_{2}\left(k_{1}^{*}\left(\overline{t_{1}}\right)\right)-z\left(E_{0}-k_{1}^{*}\left(\overline{t_{1}}\right)\right)=0 \text {. }
$$

Differentiating this condition with respect to $E_{0}$ and simplifying yields

$$
\left[\frac{1}{(1+r)} t_{2} f_{2}^{\prime}\left(k_{1}^{*}\left(\overline{t_{1}}\right)\right)+z\right] \frac{d k_{1}^{*}}{d t_{1}} \frac{d \overline{t_{1}}}{d E_{0}}=z .
$$

Since $f_{2}^{\prime}>0$ and $\frac{d k_{1}^{*}}{d t_{1}}<0$, it follows that $\frac{d \overline{t_{1}}}{d E_{0}}<0$.

Similarly, differentiating condition (23) with respect to $z$ and simplifying yields

$$
\left[\frac{1}{(1+r)} t_{2} f_{2}^{\prime}\left(k_{1}^{*}\left(\overline{t_{1}}\right)\right)+z\right] \frac{d k_{1}^{*}}{d t_{1}} \frac{d \overline{t_{1}}}{d z}+k_{1}^{*}\left(\overline{t_{1}}\right)=E_{0} \text {. }
$$


Since $k_{1}^{*}\left(\overline{t_{1}}\right)<E_{0}$ (investment is bounded above by economy's endowment), it follows that $\frac{d \overline{t_{1}}}{d z}<0$. Q.E.D.

Lemma 2: Note that the optimal interior tax-rate $t_{1}^{A}$ in the ability-to-pay region satisfies equation (9) which is independent of $E_{0}$ and $z$. The rest of the lemma follows from the properties of $\overline{t_{1}}$ derived in Lemma 1. Q.E.D.

Lemma 3: Recall that $t_{1}^{A}$ is given by the first-order condition (9) and $t_{1}^{W}$ is given by the first-order condition (11). Since second-order condition is assumed to be met for both problems (see footnotes 9 and 10), and because $\frac{d k_{1}^{*}}{d t_{1}}<0$, it follows that $t_{1}^{W}>t_{1}^{A}$. The properties of $t_{1}^{W}$ in endowment $E_{0}$ and default cost $z$ follow similarly to proof in Lemma 1 by taking derivatives of equation (11) with respect to $E_{0}$ and $z$, respectively. Q.E.D. Proposition 1, Corollary 1 and Corollary 2: From Lemma 1, ability-to-pay constraint applies if tax rate is above $\bar{t}_{1}$ and willingness-to-pay constraint applies otherwise.

Further, from Lemma $3, t_{1}^{W}>t_{1}^{A}$. Hence, the three cases to consider are: $(i) t_{1}^{W} \geq t_{1}^{A}>\overline{t_{1}}$; (ii) $t_{1}^{W} \geq \overline{t_{1}} \geq t_{1}^{A}$; and, (iii) $\overline{t_{1}}>t_{1}^{W} \geq t_{1}^{A}$.

Under case (i), the feasible region is the ability-to-pay region, so that tax rate is set at the optimal interior tax rate $t_{1}^{A}$ which from Lemma 2 is independent of $E_{0}$ and $z$. Under case (ii), the feasible region is just the threshold point $\bar{t}_{1}$, which from Lemma 1 is decreasing in $E_{0}$ and $z$. 
Under case (iii), the feasible region is the willingness-to-pay region, so that tax rate is set at the optimal interior tax rate $t_{1}^{W}$ which from Lemma 3 is independent of $E_{0}$ but increasing in $z$.

Whether the equilibrium is in regions (i), (ii) or (iii) is determined by levels of parameters $E_{0}$ and $z$. Consider first the effect of varying $E_{0}$. As $E_{0}$ is raised, the optimal interior tax rates $t_{1}^{W}$ and $t_{1}^{A}$ corresponding to the willingness-to-pay and ability-to-pay regions, respectively, are unaffected, whereas the threshold rate $\overline{t_{1}}$ declines. It follows then that there exists threshold levels of $E_{0}$ (say $\overline{E_{0}}$ and $\underline{E_{0}}$ ) above and below which respectively case (i) and (iii) apply. Under case (i), the tax rate is $t_{1}^{A}$, which is independent of $E_{0}$; under case (iii), $t_{1}^{W}$ which from Lemma 3 is independent of $E_{0}$; and in between the thresholds, the tax rate is $\overline{t_{1}}$, which from Lemma 1 is decreasing in $E_{0}$. Consider next the effect of varying $z$. As $z$ is raised, $t_{1}^{A}$ is unaffected, $\overline{t_{1}}$ declines, whereas $t_{1}^{W}$ rises. It follows then that there exists threshold levels of $z$ (say $\bar{z}$ and $\underline{z}$ ) above and below which respectively case (i) and (iii) apply. Under case (i), the tax rate is $t_{1}^{A}$, which is independent of $z$; under case (iii), the tax rate is $t_{1}^{W}$ which from Lemma 3 is increasing in $z$; and in between the thresholds, the tax rate is $\overline{t_{1}}$, which is decreasing in $z$.

Finally, consider the debt capacity $D_{1}^{*}=\min \left[\frac{1}{(1+r)} t_{2} f_{2}\left(k_{1}^{*}\left(t_{1}^{*}\right)\right), z\left(E_{0}-k_{1}^{*}\left(t_{1}^{*}\right)\right)\right]$. As explained above, in the ability-to-pay region (first term inside square brackets), the tax rate $t_{1}^{*}$ is set to $t_{1}^{A}$ which is independent of $E_{0}$ (Lemma 2). Then, since 
$\frac{d D_{1}^{*}}{d E_{0}}=\frac{1}{(1+r)} t_{2} f_{2}^{\prime}\left(k_{1}^{*}\left(t_{1}^{*}\right)\right) \frac{d k_{1}^{*}}{d t_{1}} \frac{d t_{1}^{*}}{d E_{0}}$, in this region we have $\frac{d D_{1}^{*}}{d E_{0}}=0$. Similarly, we obtain that $\frac{d D_{1}^{*}}{d z}=0$ in this region.

In contrast, in the willingness-to-pay region (second term inside square brackets), the tax rate $t_{1}^{*}$ is set to $t_{1}^{W}$. In this case, $\frac{d D_{1}^{*}}{d E_{0}}=z\left(1-\frac{d k_{1}^{*}}{d t_{1}^{*}} \frac{d t_{1}^{*}}{d E_{0}}\right)>0$ since $\frac{d k_{1}^{*}}{d t_{1}^{*}}<0$ and $\frac{d t_{1}^{*}}{d E_{0}}=0$ for $t_{1}^{*}=t_{1}^{W}$ (Lemma 3). Similarly, $\frac{d D_{1}^{*}}{d z}=\left(E_{0}-k_{1}^{*}\left(t_{1}^{*}\right)\right)-z \frac{d k_{1}^{*}}{d t_{1}^{*}} \frac{d t_{1}^{*}}{d z}>0$ since $\frac{d k_{1}^{*}}{d t_{1}^{*}}<0$ and $\frac{d t_{1}^{*}}{d z}>0$ for $t_{1}^{*}=t_{1}^{W}($ Lemma 3$)$.

In the intermediate region, the tax rate is set to $\bar{t}_{1}$. Now, since $f_{2}^{\prime}>0, \frac{d k_{1}^{*}}{d t_{1}^{*}}<0$ and $\frac{d t_{1}^{*}}{d E_{0}}<0$ (Lemmas 1), it follows that $\frac{d D_{1}^{*}}{d E_{0}}>0$. Similarly, it can be shown that $\frac{d D_{1}^{*}}{d z}>0$ in this region.

Q.E.D.

Proposition 2: From equation (15), the threshold level of legacy debt $D_{0}^{\operatorname{Max}}$ above which the short-horizon government defaults is given by $t_{1}^{* *} f_{1}\left(k_{1}^{*}\left(t_{1}^{* *}\right)\right)=D_{1}^{*}-D_{0}^{\operatorname{Max}}(1+r)+t_{1}^{*} f_{1}\left(k_{1}^{*}\left(t_{1}^{*}\right)\right)$. The no-default case debt capacity is $D_{1}^{*}=\min \left[\frac{1}{(1+r)} t_{2} f_{2}\left(k_{1}^{*}\left(t_{1}^{*}\right)\right), z\left(E_{0}-k_{1}^{*}\left(t_{1}^{*}\right)\right)\right]$ where the no-default case tax rate $t_{1}^{*}$ is as characterized in Proposition 1. The default-case tax rate $t_{1}^{* *}$ is given by condition (14). Then, it follows that 


$$
(1+r) \frac{d D_{0}^{M a x}}{d E_{0}}=\frac{d}{d E_{0}}\left[D_{1}^{*}-t_{1}^{* *} f_{1}\left(k_{1}^{*}\left(t_{1}^{* *}\right)\right)+t_{1}^{*} f_{1}\left(k_{1}^{*}\left(t_{1}^{*}\right)\right)\right] \text {. }
$$

From (14), $\frac{d t_{1}^{* *}}{d E_{0}}=0$. And, $\frac{d}{d E_{0}}\left[D_{1}^{*}+t_{1}^{*} f_{1}\left(k_{1}^{*}\left(t_{1}^{*}\right)\right)\right]=\frac{\partial}{\partial E_{0}}\left[D_{1}^{*}+t_{1}^{*} f_{1}\left(k_{1}^{*}\left(t_{1}^{*}\right)\right)\right]$ by envelope theorem as $t_{1}^{*}$ is chosen by the short-horizon government to maximize $D_{1}^{*}+t_{1}^{*} f_{1}\left(k_{1}^{*}\left(t_{1}^{*}\right)\right)$. Since $\frac{\partial}{\partial E_{0}}\left[D_{1}^{*}+t_{1}^{*} f_{1}\left(k_{1}^{*}\left(t_{1}^{*}\right)\right)\right]=\frac{\partial D_{1}^{*}}{\partial E_{0}} \geq 0$, it follows that $\frac{d D_{0}^{\operatorname{Max}}}{d E_{0}} \geq 0$. Similar arguments show that $\frac{d D_{0}^{\operatorname{Max}}}{d z} \geq 0$. Q.E.D.

Proposition 3: Differentiating equation (19) w.r.t. $\beta$ when $\beta<\frac{1}{(1+r)}$ (the other case being discussed in text),

$$
\frac{d D_{0}^{\operatorname{Max}}}{d \beta}=\frac{1}{(1+r)}\left[\frac{d D_{1}^{*}}{d \beta}(1-\beta(1+r))-D_{1}^{*}(1+r)+\left.\frac{d G}{d t_{1}}\right|_{t_{1}^{*}} \frac{d t_{1}^{*}}{d \beta}-\left.\frac{d G}{d t_{1}}\right|_{t_{1}^{* *}} \frac{d t_{1}^{* *}}{d \beta}\right] .
$$

As explained in the text, in the ability-to-pay region, $D_{1}=\frac{t_{2} f_{2}}{1+r}$ and $t_{1}^{A, \beta=0}=t_{1}^{A, \beta>0}$. Hence, in this region, $\frac{d D_{1}^{*}}{d \beta}=0$ and $\frac{d t_{1}^{*}}{d \beta}=0$. By definition of $t_{1}^{* *}, \frac{d G}{d t_{1}}=0$ at $t_{1}^{* *}$. It follows then that in the ability-to-pay region, $\frac{d D_{0}{ }^{\operatorname{Max}}}{d \beta}=-D_{1}^{*}<0$. The same arguments apply for the case when both constraints bind as $\overline{t_{1}^{\beta=0}}=\overline{t_{1}^{\beta>0}}$.

In contrast, in the willingness-to-pay region, we obtain by applying envelope theorem to the first-order condition (17) that

$$
(\operatorname{soc}) \cdot \frac{d t_{1}^{W}}{d \beta}+\left[z(1+r)+t_{2} f_{2}^{\prime}\right] \frac{d k_{1}^{*}}{d t_{1}}=0
$$


where (soc) is the second-order condition, assumed to be negative. Then, since $f_{2}^{\prime}>0$ and $\frac{d k_{1}^{*}}{d t_{1}}<0$, it follows that $\frac{d t_{1}^{W}}{d \beta}<0$. Further, in this region, $\frac{d D_{1}^{*}}{d \beta}=-z \frac{d k_{1}^{*}}{d t_{1}^{W}} \frac{d t_{1}^{W}}{d \beta}<0$. Finally, substituting the first-order condition (17) into $\left.\frac{d G}{d t_{1}}\right|_{t_{1}^{*}}$, we obtain that $\left.\frac{d G}{d t_{1}}\right|_{t_{1}^{*}}$ equals $[1-\beta(1+r)] z \frac{d k_{1}^{*}}{d t_{1}}$. Then, substituting the various pieces in (28) and simplifying, we obtain that $\frac{d D_{0}^{\operatorname{Max}}}{d \beta}=-z\left[E_{0}-k_{1}^{*}\left(t_{1}^{W}\right)\right]<0$. Q.E.D.

Proposition 4: Note that the optimal tax rate $t_{1}^{*}$ is given by the condition (foc)

$\left[\left(\frac{q}{1+r}-\beta(1-q)\right) t_{2} f_{2}^{H^{\prime}}+t_{1} f_{1}^{\prime}\right] \frac{d k_{1}^{*}}{d t_{1}}+f_{1}=0$. The corresponding second-order condition (soc) is assumed to be negative. Then, differentiating the (foc) w.r.t. $\beta$, it follows that $\frac{d t_{1}^{*}}{d \beta}$ has the same sign as $\frac{\partial(f o c)}{\partial \beta}=-(1-q) t_{2} f_{2}^{H^{\prime}} \frac{d k_{1}^{*}}{d t_{1}} \geq 0$ since $\frac{d k_{1}^{*}}{d t_{1}}<0$. Then, $\frac{d D_{1}^{*}}{d \beta}=\frac{t_{2}}{(1+r)} f_{2}^{H^{\prime}} \frac{d k_{1}^{*}}{d t_{1}^{*}} \frac{d t_{1}^{*}}{d \beta}<0$ and $\frac{d z^{*}}{d \beta}=$ $\frac{t_{2}}{(1+r)\left[E_{0}-k_{1}^{*}\right]^{2}}\left[\left[E_{0}-k_{1}^{*}\right] f_{2}^{H^{\prime}}+f_{2}^{H}\right] \frac{d k_{1}^{*}}{d t_{1}^{*}} \frac{d t_{1}^{*}}{d \beta}<0$.

Similarly, $\frac{d t_{1}^{*}}{d q}$ has the same sign as $\frac{\partial(f o c)}{\partial q}=\left[\frac{1}{(1+r)}+\beta\right] t_{2} f_{2}^{H^{\prime}} \frac{d k_{1}^{*}}{d t_{1}}<0$. Further, since the (foc) for private sector's choice of $k_{1}^{*}$ is given by $\frac{1}{(1+r)}\left(1-t_{1}\right) f_{1}^{\prime}\left(k_{1}\right)+\frac{1}{(1+r)^{2}}\left(1-t_{2}\right) q f_{2}^{H^{\prime}}\left(k_{1}\right)-1=0$, differentiation of (foc) w.r.t. $q$ and 


$$
\begin{aligned}
& \text { assuming (soc) }<0 \text {, yields that } \frac{\partial k_{1}^{*}}{\partial q}>0 \text {. Then, } \frac{d D_{1}^{*}}{d q}=\frac{t_{2}}{(1+r)} f_{2}^{H^{\prime}}\left[\frac{\partial k_{1}^{*}}{\partial q}+\frac{d k_{1}^{*}}{d t_{1}^{*}} \frac{d t_{1}^{*}}{d q}\right]>0 \text { and } \\
& \frac{d z^{*}}{d q}=\frac{t_{2}}{(1+r)\left[E_{0}-k_{1}^{*}\right]^{2}}\left[\left[E_{0}-k_{1}^{*}\right] f_{2}^{H^{\prime}}+f_{2}^{H}\right]\left[\frac{\partial k_{1}^{*}}{\partial q}+\frac{d k_{1}^{*}}{d t_{1}^{*}} \frac{d t_{1}^{*}}{d q}\right]>0 \text {. Q.E.D. }
\end{aligned}
$$

\section{Appendix B: Example}

Under the choice of functional forms $f_{1}(k)=\alpha \theta k^{\gamma}, f_{2}(k)=(1-\alpha) \theta k^{\gamma}$, we obtain the following solutions for analysis of Section II, which are employed in generation of Figures 2-7:

$k_{1}^{*}\left(t_{1}\right)=\left(\frac{\gamma \theta}{(1+r)}\left[\left(1-t_{1}\right) \alpha+\frac{\left(1-t_{2}\right)(1-\alpha)}{(1+r)}\right]\right)^{\frac{1}{(1-\gamma)}}$.

$\bar{t}_{1}$ is given implicitly (as it affects $k^{*}$ ) by the condition

$\frac{t_{2}(1-\alpha) \theta\left(k^{*}\right)^{\gamma}}{z(1+r)}+k^{*}=E_{0}$.

$t_{1}^{A}$ satisfies the condition

$\gamma\left[t_{1} \alpha+\frac{t_{2}(1-\alpha)}{(1+r)}\right]=(1-\gamma)\left[\left(1-t_{1}\right) \alpha+\frac{\left(1-t_{2}\right)(1-\alpha)}{(1+r)}\right]$.

$t_{1}^{W}(\beta)$ is given by the condition

$\gamma\left[t_{1} \alpha+\beta t_{2}(1-\alpha)\right]=\left[(1-\gamma)+\gamma z\left(\frac{1}{(1+r)}-\beta\right)\right] \cdot\left[\left(1-t_{1}\right) \alpha+\frac{\left(1-t_{2}\right)(1-\alpha)}{(1+r)}\right]$

Then, $t_{1}^{*}$ and $D_{1}^{*}$ are given respectively as

$t_{1}^{*}=t_{1}^{A}$ if $t_{1}^{W} \geq t_{1}^{A}>\bar{t}_{1} ; \bar{t}_{1}$ if $t_{1}^{W} \geq \bar{t}_{1} \geq t_{1}^{A}$; and $t_{1}^{W}$ otherwise, and 


$$
D_{1}^{*}=\min \left[\frac{1}{(1+r)} t_{2} f_{2}\left(k_{1}^{*}\left(t_{1}^{*}\right)\right), z\left(E_{0}-k_{1}^{*}\left(t_{1}^{*}\right)\right)\right]
$$

Once in default, the tax policy $t_{1}^{* *}(\beta)$ is given by the condition

$$
\gamma\left[t_{1} \alpha+\beta t_{2}(1-\alpha)\right]=(1-\gamma)\left[\left(1-t_{1}\right) \alpha+\frac{\left(1-t_{2}\right)(1-\alpha)}{(1+r)}\right]
$$

In turn, the threshold level of legacy debt above which the government defaults is given by

$$
\begin{aligned}
& D_{0}^{M a x}=\frac{1}{(1+r)}\left[D_{1}^{*}(1-\beta(1+r))+G\left(t_{1}^{*}\right)-G\left(t_{1}^{* *}\right)\right], \text { where } \\
& G\left(t_{1}\right)=\left[t_{1} \alpha+\beta t_{2}(1-\alpha)\right] \theta\left(k^{*}\left(t_{1}\right)\right) .
\end{aligned}
$$


Figure 2: Short-horizon government's tax policy (rate) as a function of endowment

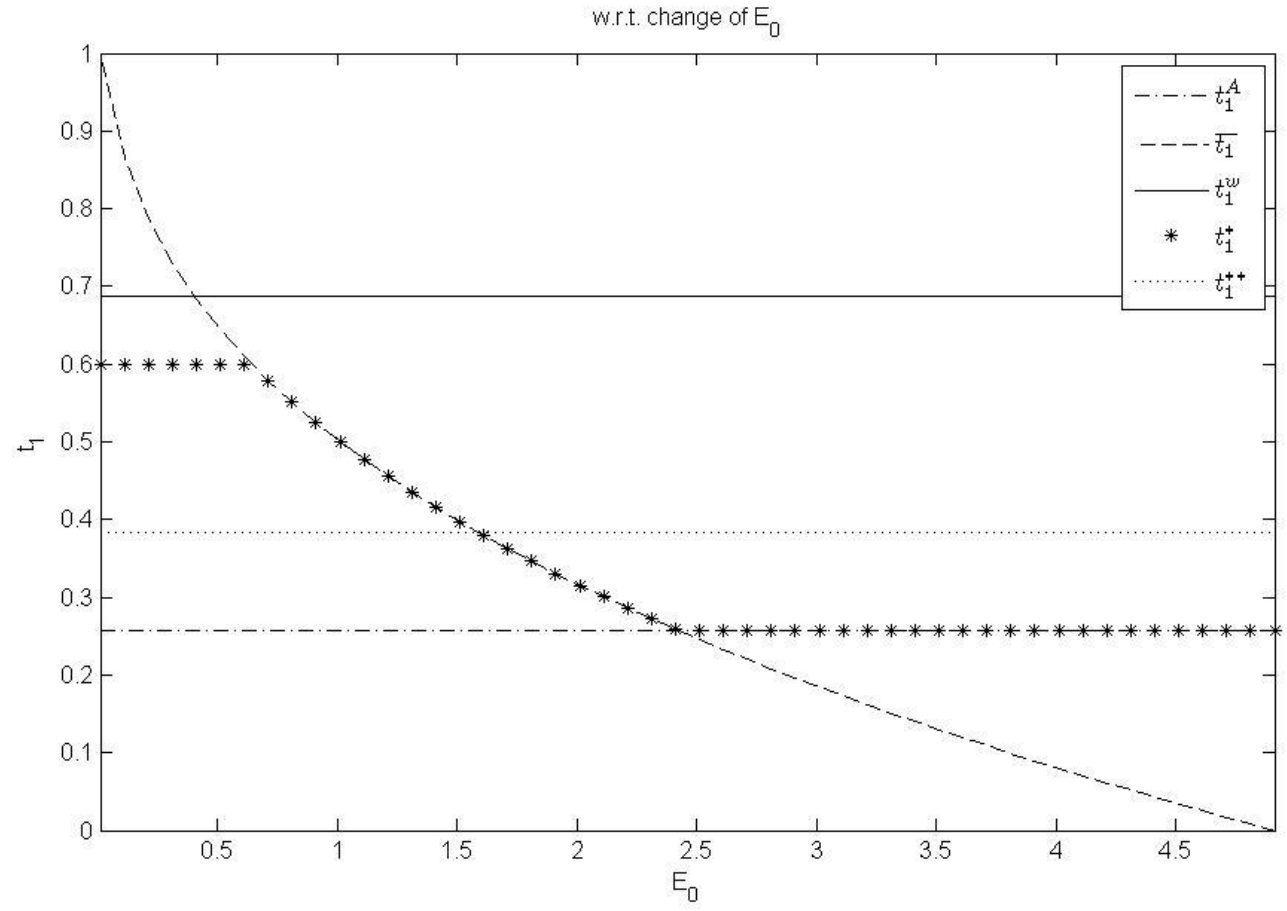

Figure 3: Short-horizon government's debt capacity as a function of endowment

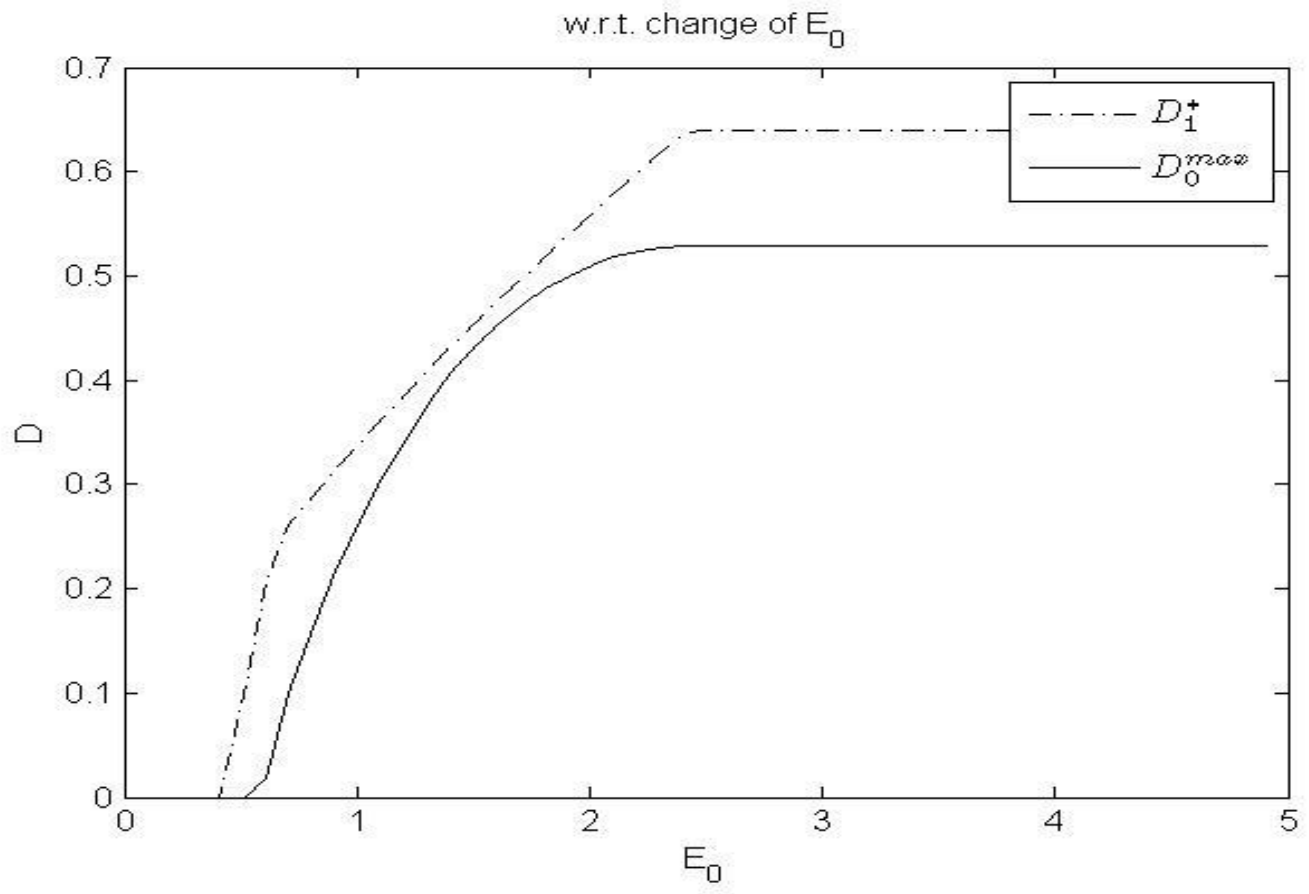


Figure 4: Short-horizon government's tax policy (rate) as a function of productivity

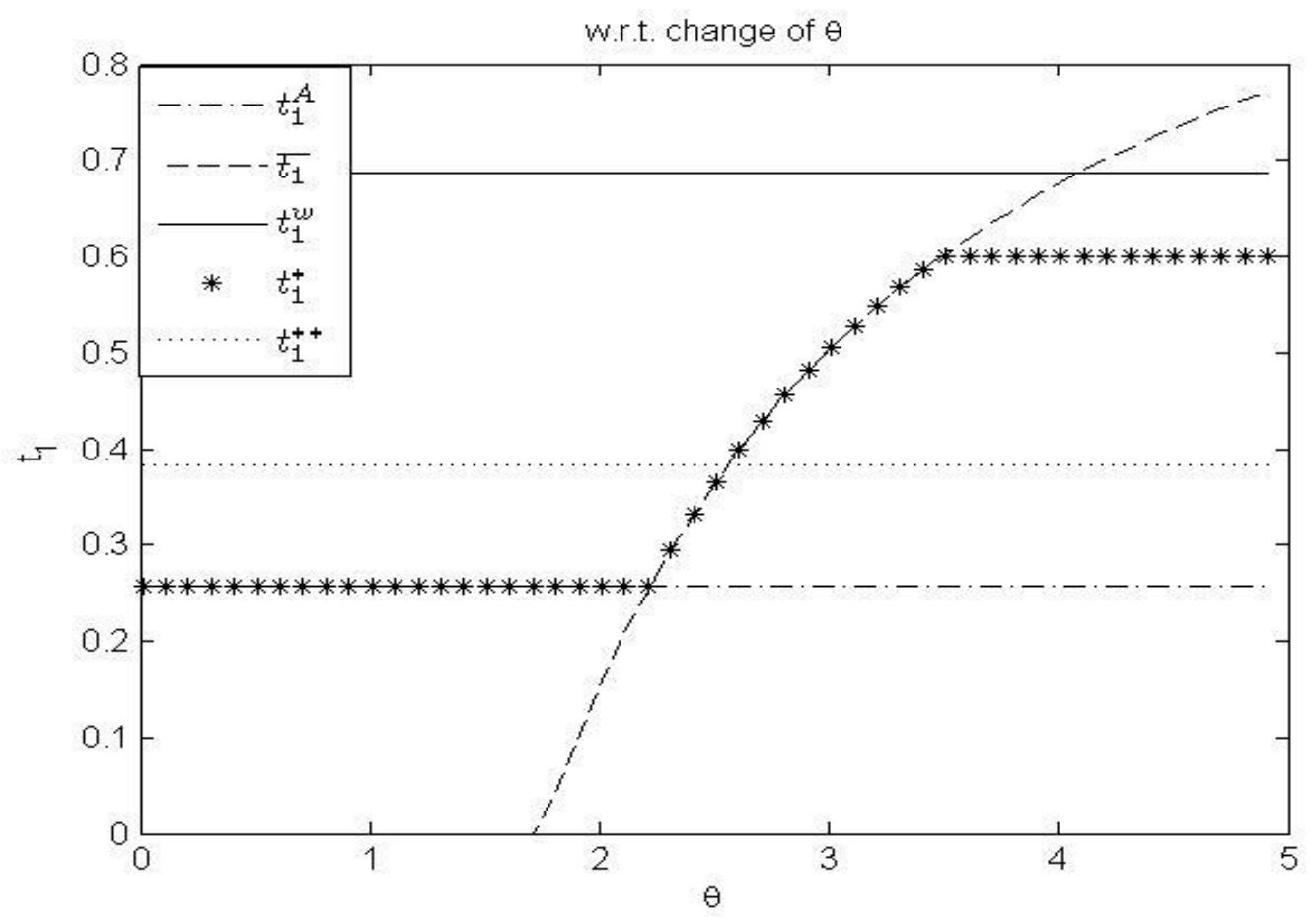

Figure 5: Short-horizon government's debt capacity as a function of productivity

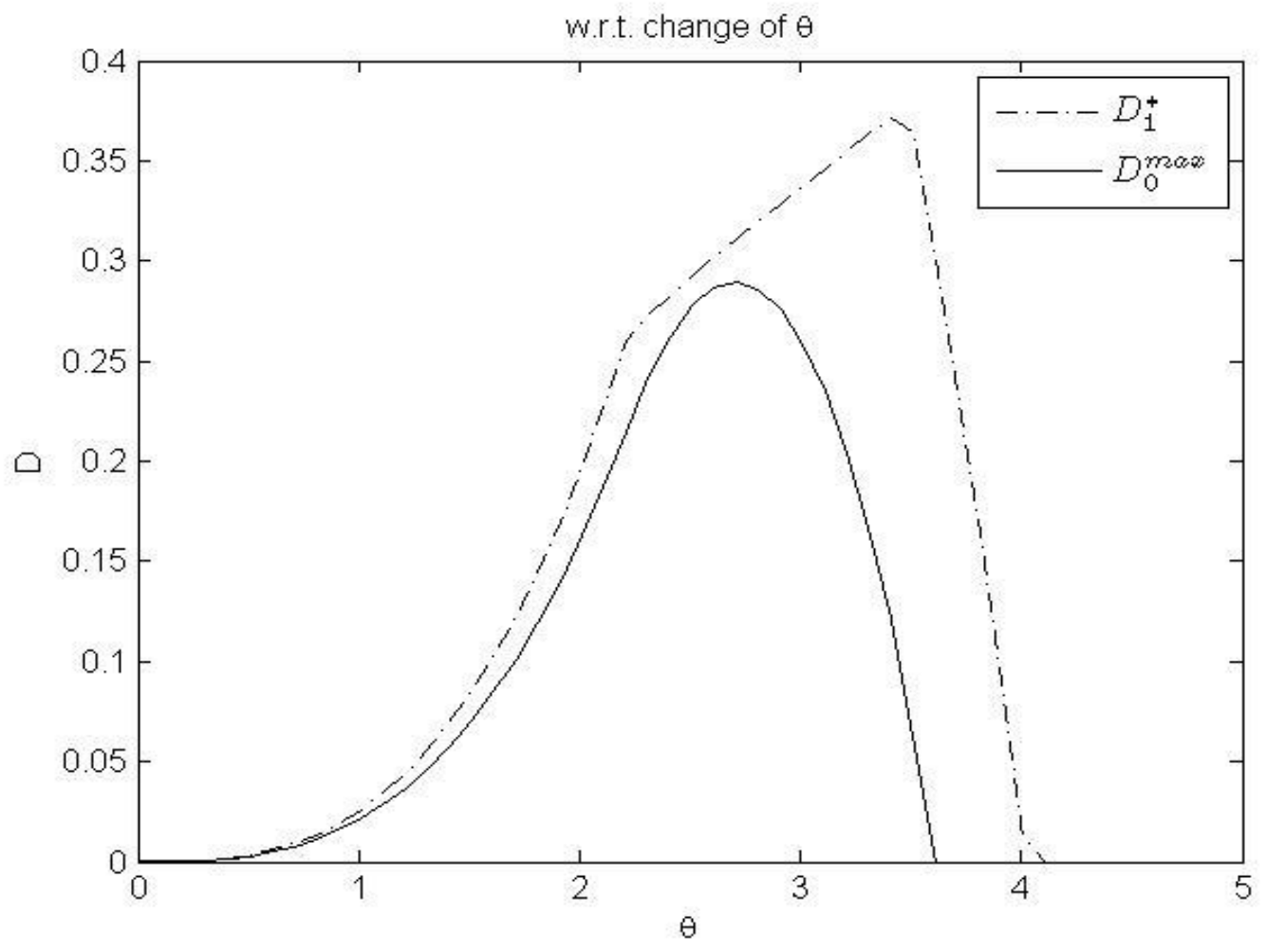


Figure 6a: Government's tax policy as a function of myopia for varying endowment

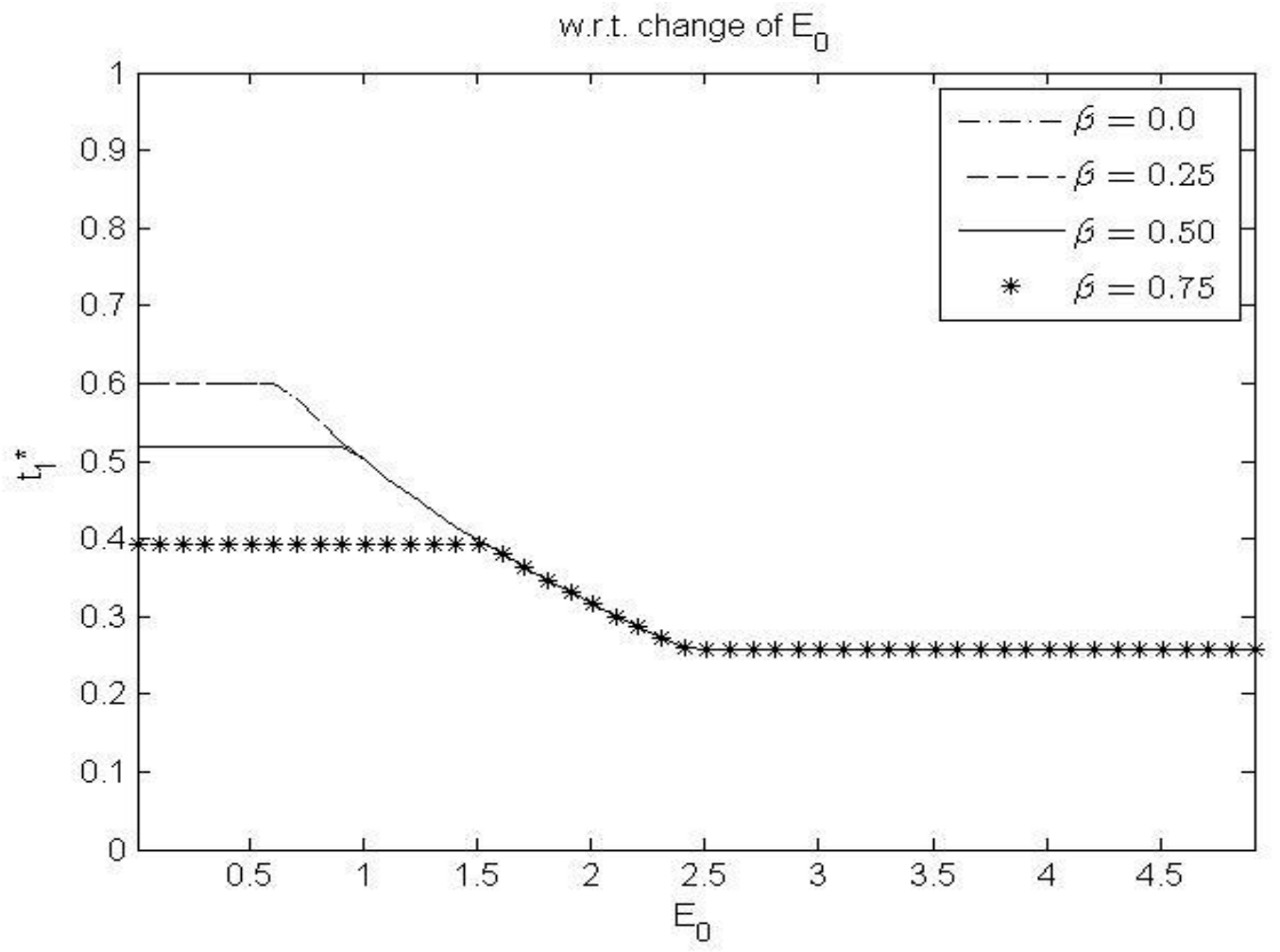

Figure 6b: Government's debt capacity as a function of myopia for varying endowment

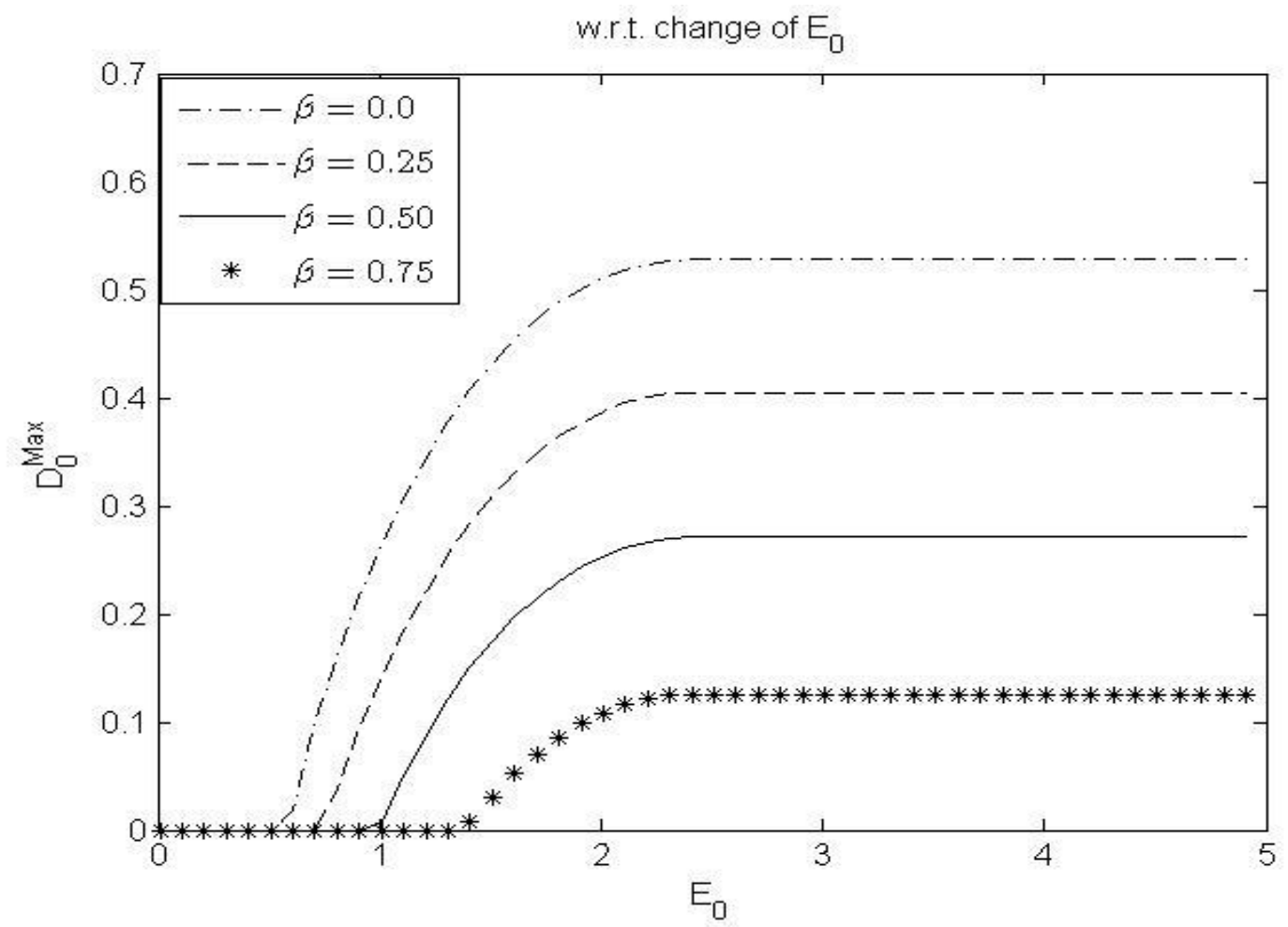


Figure 7a: Government's tax policy as a function of myopia for varying productivity

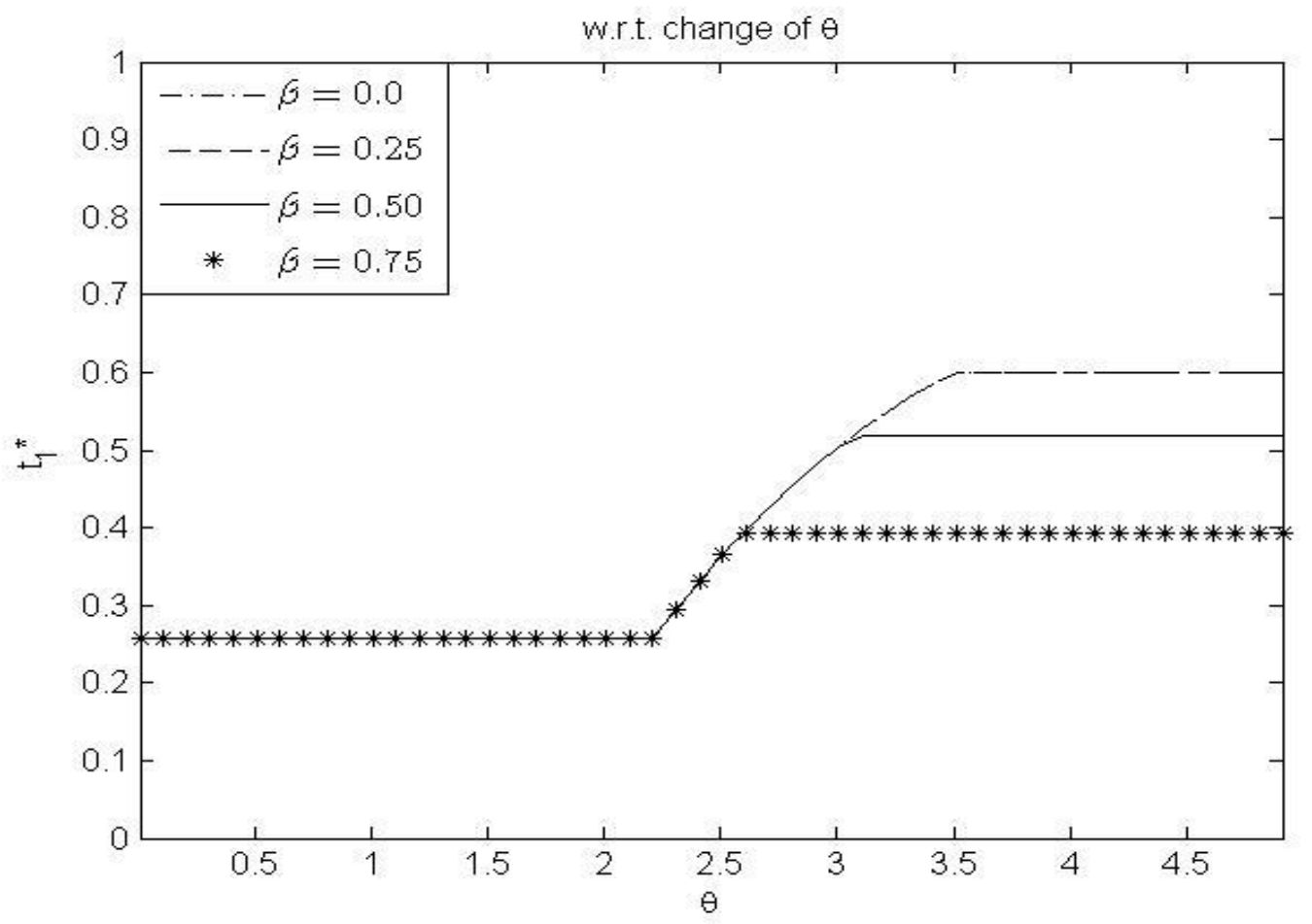

Figure 7b: Government's debt capacity as a function of myopia for varying productivity

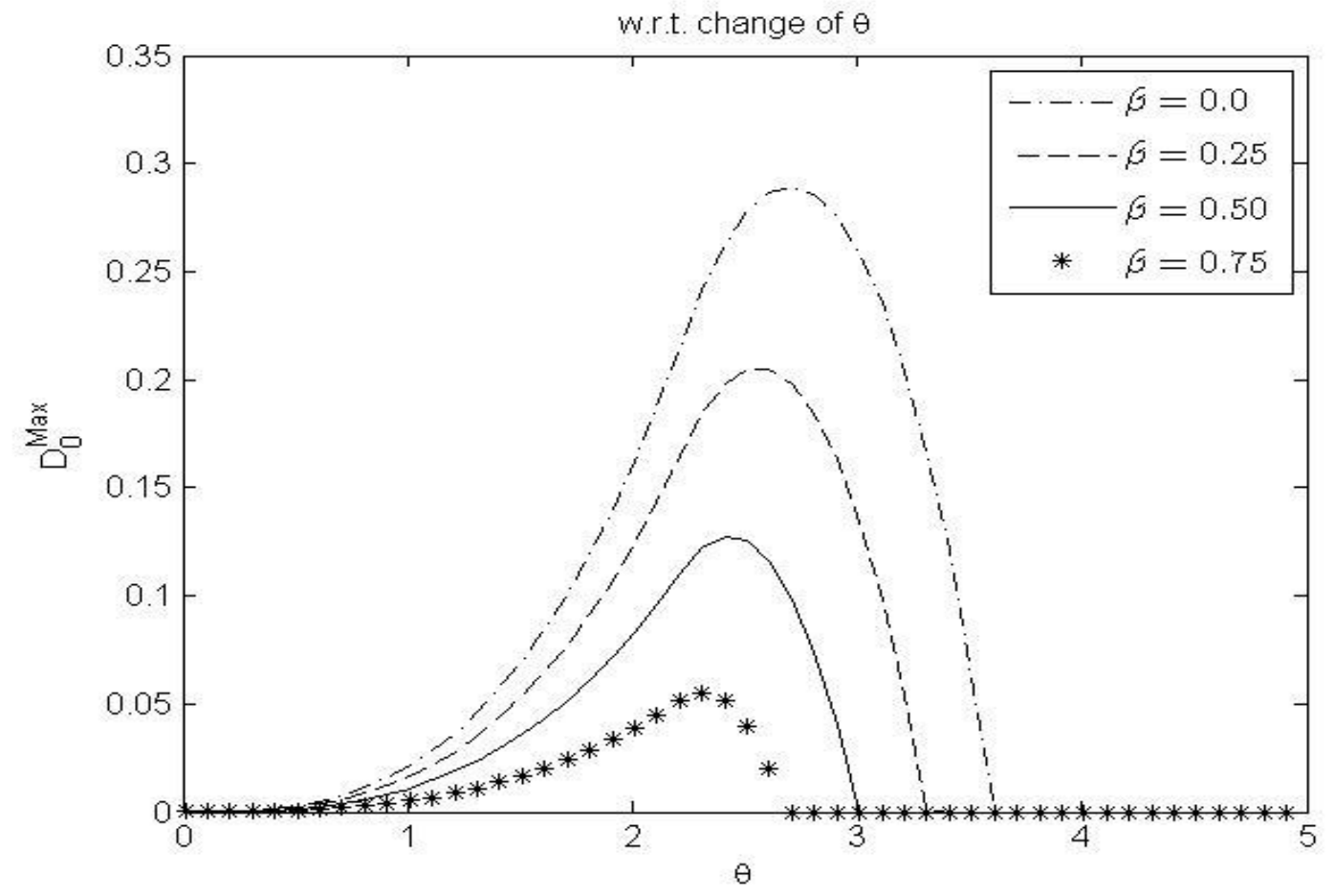

